\title{
The Shadow of the Gallows: The Death Penalty and the British Labour Government, 1945-51
}

\author{
VICTOR BAILEY
}

It is queer to look back and think that only a dozen years ago the abolition of the death penalty was one of those things that every enlightened person advocated as a matter of course, like divorce reform or the independence of India. Now, on the other hand, it is a mark of enlightenment not merely to approve of executions but to raise an outcry because there are not more of them.

\section{—George Orwell}

The punishment prescribed by English law for murder in the first half of the twentieth century was death. A judge had to pronounce this sentence upon a person convicted of murder, except in two special classes of cases: persons under eighteen years of age at the time of the offense and pregnant women. ${ }^{1}$ He had no discretion to impose any less severe sentence.

1. From 1887, executions for those under eighteen were virtually abolished by use of the royal prerogative of mercy. The Children Act, 1908, formally abolished the death penalty for persons under sixteen; the Children and Young Persons Act, 1933, confirmed the existing practice of reprieve by ending capital punishment for those under eighteen. The Sentence of Death (Expectant Mothers) Act, 1931, prohibited the death sentence on a pregnant woman. In addition, by the 1922 Infanticide Act, a woman charged with the death of her "newly born"- a term undefined in the Act, and narrowly interpreted by the courts, but

Victor Bailey is Professor of Modern British History at the University of Kansas. He is grateful to the University of Kansas for the General Research Fund award that made it possible to complete this article. He would also like to thank Sheila Blackburn, Karl Brooks, Jonathan Clark, Ken Morgan, Elaine Reynolds, Lisa Steffen, the members of the British Seminar at Kansas University, and the anonymous reviewers for their valuable comments on an earlier draft of this article. 
While retribution survived only in a symbolic form elsewhere in the criminal law, capital punishment, as Oxford criminologist Max Grunhut maintained, was a "powerful relic of retaliation in kind." The law still reflected the ancient concept that every murderer forfeits his life because he has taken another's life: "He that smiteth a man, so that he die, shall be surely put to death."2

In practice, the rigidity of the law was mitigated by the exercise of the royal prerogative of mercy, which rested in the hands of the home secretary, the government minister responsible, among other things, for the police and prison services. The effect of a reprieve, before 1948, was to reduce the sentence to penal servitude for life. ${ }^{3}$ In the fifty-year period from 1900 through 1949, 1,210 persons were sentenced to death in England and Wales (1,080 men and 130 women). Five hundred and fifty-three, or 45.7 percent, had their sentences commuted or respited. ${ }^{4} \mathrm{~A}$ larger percentage of female murderers ( 90.8 percent) benefited from the prerogative of mercy than males ( 40.3 percent). The first figure indicates considerable reluctance to apply the death penalty to a woman. The remaining 632 (or 52.2 percent of those sentenced to death) were executed for murder ( 621 men and 11 women), making an execution rate of 13 a year between 1900 and $1949 .^{5}$

enlarged in 1938 to apply to the death of a child under twelve months of age-would be punished for the commission of manslaughter rather than murder. This change meant little in practice, because no woman had been executed for the murder of her baby since 1849. It simply brought law and practice into conformity. See Gordon Rose, The Struggle for Penal Reform (London: Stevens and Sons, 1961), 202, 206; Christopher Hollis, The Homicide Act (London: Victor Gollancz, 1964), 13; P. G. Richards, Parliament and Conscience (London: George Allen and Unwin, 1970), 37.

2. Max Grunhut, "Murder and the Death Penalty in England," Annals of the American Academy of Political and Social Science 284 (1952): 158; Exodus 21:12.

3 . This sentence did not typically mean life, of course. Of the 253 commuted death sentence cases where release was authorized between 1920 and 1948, 58 (or 23 percent) were released after less than five years' detention, 141 (or 56 percent) after less than ten years' detention, and 236 (or 93 percent) after less than sixteen years' detention. See Home Office, Capital Punishment, Cmd. 7419 (London: Her Majesty's Stationery Office, 1948), 1.

4. Forty-seven were certified insane (respited to Broadmoor); 506 were reprieved (their sentence commuted to penal servitude).

5. Twenty-three had their conviction quashed by the Court of Appeal. The figures in this paragraph are drawn from Royal Commission on Capital Punishment, 1949-1953, Cmd. 8932 (1953; reprint, London: Her Majesty's Stationery Office, 1965), 13 (table 3), 19, and 298301 (appendix 3, table 1); Select Committee on Capital Punishment, Parliamentary Papers (P.P.), 1930-31, VI (15), Report, 14; Harry Potter, Hanging in Judgment: Religion and the Death Penalty in England (New York: Continuum, 1993), 143, 243, n. 4. The death penalty was, in practice, confined to murder, except for wartime executions for treason. In addition, eighteen U.S. soldiers (over half of whom were African Americans) were executed for murder or rape (or a combination of the two) in England during the Second World War, under the Visiting Forces Act, 1942. See J. Robert Lilly and J. Michael Thomson, "Executing US 
The annual number of hangings was in large part, then, a function of the use of the reprieve power.

The law reformers of the early nineteenth century had successfully whittled the number of capital offenses down to the four that remained in the twentieth century: murder, treason, piracy with violence, and arson in government dockyards and arsenals. But they and their successors, while restricting the application of the death penalty to the gravest crimes, had failed to secure the complete abolition of capital punishment. The only proposal of the Royal Commission on Capital Punishment (1864-66) to be accepted was the prohibition of public execution; from 1868, executions were carried out within prison confines. The six subsequent attempts between 1866 and 1891 to divide murder into two degrees, capital and noncapital, which the Royal Commission had also proposed (on the model widely used in the United States), all failed. By 1918, the influence of the abolitionists was at its nadir. But from that point on, things improved rapidly. The emergence of the Labour Party in 1906, and its rise to become the main opposition to the Conservative Party by the 1920s, changed the parliamentary dynamics of the capital punishment debate. For the first time, abolitionists had the sympathetic ear of a principal political party.

The achievements of the first two Labour governments of 1924 and 192931 were limited. Nonetheless, by the end of the 1930s, the number executed each year was at an all-time low; support for abolition in Parliament and among the public was arguably at an all-time peak. Little wonder that hopes ran high in abolitionist circles when the first Labour government with a parliamentary majority was elected in 1945, at the end of the Second World War, on a floodtide of popular support for a juster, more humane society. It was confidently expected that the 1938 Criminal Justice Bill, which had been abandoned at the outbreak of war in 1939, would be resurrected, and that a clause eliminating the death penalty for murder would find a place in the new version. The 1947 Criminal Justice Bill, though shaped almost entirely by prewar thought, was part and parcel of the postwar Labour government's program to reconstruct the social and economic framework of the country. Like its 1938 predecessor, the postwar bill concentrated upon two categories: young and persistent offenders. It sought to keep young offenders out of prison, especially by providing new alternatives to impris-

Soldiers in England, World War II," British Journal of Criminology 37 (1997): 262-88. Between 1900 and 1965, the year when capital punishment for murder was suspended, 780 civilians were hanged in Britain after being convicted of murder. See Christie Davies, "The British State and the Power of Life and Death," in The Boundaries of the State in Modern Britain, ed. S. J. D. Green and R. C. Whiting (Cambridge: Cambridge University Press, 1996), 342. 
onment, and to keep recidivists either in long-term "preventive detention" or under "corrective training." It also abolished corporal punishment (except in prisons), swept away the anachronistic nomenclature of "hard labour" and "penal servitude," and provided for improvements in the organization and staffing of the probation service. In all, the 1947 bill, like its precursor, aimed to eclipse the idea of retribution by further extending the principle that punishment should fit the criminal, not the crime. What better moment to abolish capital punishment, the last relic of a barbarous penal code, the one punishment in which reformation has no place? As the News Chronicle declared at the height of the ensuing battle over the death penalty, abolition "has been regarded as a pinnacle of criminal reform which we must attain before we can hold up our heads in the modern world." 6

Thus, there were great expectations; abolitionists felt victory to be within their grasp. In November 1945, the executive committee of the National Council for the Abolition of the Death Penalty advised members that the end of the war and the election of a Labour government "should bring success to our efforts for Abolition within the next few years," to ensure which "we must create from one end of the country to the other a public opinion insistently demanding Abolition." Yet three years later, following intense discussion of the subject both within and without Parliament, the abolitionists were disappointed, divided, and almost empty-handed. Anticipating the end of the death sentence for murder, abolitionists had to settle for a Royal Commission on Capital Punishment (1948-53), whose terms of reference restricted it to the possible means of limiting the operation of the death penalty, as distinct from its abolition. Few abolitionists expected an unimpeded procession toward abolition. They knew they still had worthy opponents in the senior judges, some of the principal Home Office mandarins, and the entire House of Lords. Yet few abolitionists expected the death penalty to become the paramount issue in the parliamentary debates on the Criminal Justice Bill and in the press and public discussion of the impending penal reform. Few would have forecast that the only revolt of Labour M.P.s (or the Parliamentary Labour Party) seriously to embarrass the Attlee government would arise over capital punishment. Few would have predicted that one of the two issues on which the House of Lords would exercise its delaying power would be capital punishment. ${ }^{7}$ Clearly, something went terribly wrong for the abolitionists.

6. News Chronicle, June 2, 1948, 2. For details of the 1938 and 1947 Criminal Justice Bills, see Victor Bailey, Delinquency and Citizenship: Reclaiming the Young Offender, 1914-1948 (Oxford: Oxford University Press, 1987), 255-65, 291-302.

7. NCADP, miscellaneous publications, MSS 16B/ADP/4/4/9/1, Modern Records Centre, University of Warwick Library. The other issue on which the Lords used their delaying power was the nationalization of iron and steel. See K. O. Morgan, Labour in Power, 1945-51 
Exactly what went wrong and why is the theme of this article. How and why did the Labour government, despite its massive majority in Parliament and a long-standing commitment to abolition, fail to get rid of the death penalty? Why was this "window of opportunity" to abolish capital punishment shut for another decade and a half? The answers to these questions will be sought primarily in the realm of government and Parliament. This is not as limiting as it may sound. An enduring condition of the conflict over capital punishment was that its crucial battles were fought in the main legislative fora. To limit the use of the death penalty, executive fiat in the form of more reprieves would suffice; but to abolish the penalty required changes in the law of murder that only Parliament could make. Moreover, the subject evoked such widespread lay interest, not to say passion, that the struggle over it had to be fought out in full view of the public. Accordingly, the answers to these questions have an essentially political character. Above all, the Labour government failed to take full responsibility for the death penalty. This, in turn, arose from the inclination of the government to see capital punishment as peripheral to its main business, as an issue best left to the private conscience of individual M.P.s, and hence to a free rather than a "whipped" vote of the House of Commons. ${ }^{8}$ The bulk of the government's troubles flowed from these peculiarities of the debate over the death penalty. There is, however, an additional explanation of the government's failure, one particular to the 1940s, yet one that lends wider significance to the entire evaluation.

The postwar world was much less hospitable to penal reform than the abolitionists had anticipated. For a start, the war crimes trial at Nuremberg, which began on November 20, 1945, affected the postwar mood. Judgment on the twenty-two war criminals was delivered in October 1946; twelve of the accused were sentenced to death, and ten were immediately hanged. ${ }^{9}$

(Oxford: Oxford University Press, 1985), 62, 84; R. F. V. Heuston, Lives of the Lord Chancellors, 1940-1970 (Oxford: Oxford University Press, 1987), 127.

8. The members of Parliament who have the job of delivering each party's vote in the House of Commons are known as "whips"; hence, a "whipped" vote is one in which M.P.s have no choice but to vote for their party; a free vote is when M.P.s are allowed to vote the way their conscience dictates. The free vote is generally permitted when the subject is deemed to be an issue of public morality that cuts across party lines. Any divisions are not taken as votes of confidence in the government. Almost all bills dealing with capital punishment have been put to free votes on some or all of their stages. It is arguable, however, that capital punishment rarely cut across party lines, despite the pretence that it did. For most of this century, Labour and Liberal M.P.s have typically voted against capital punishment, while Conservative M.P.s have typically voted in favor. See Davies, "Power of Life and Death," 343.

9. One of those condemned to death-Martin Bormann-was sentenced in absentia; Hermann Goring cheated the hangman by committing suicide. See Peter Calvocoressi, Nuremberg: The Facts, the Law and the Consequences (New York: Macmillan, 1948); Werner Maser, Nuremberg: A Nation on Trial (New York: Scribner, 1979). 
For some people, Nuremberg lent justification to a retributive approach to indigenous murder. More influential was the rise in officially recorded crime and the "moral panic" the figures generated. ${ }^{10}$ The press was full of the senseless violence of juvenile gangs and of the sordid and meaningless nature of contemporary homicide, a theme taken up by George Orwell in his 1946 essay on the changed character of murder. ${ }^{11}$ This crime-wave narrative had an effect upon penal thought, notably by reinvigorating the belief that punitive measures could not be surrendered. The reforming tide of the 1920s and 1930s can be exaggerated, but there is no doubt that this tide was turned back in the 1940 s, at least to some degree, by the combined pressure of the senior judges, the lord chancellor, and the House of Lords, and with the effective deployment of majority public opinion. Inevitably, the debate over the abolition of the death penalty became embroiled in this pronounced attack upon reformist sentiment. The fact that at one of the most propitious moments for abolition, an impassioned debate ended with the survival of this retributive symbol, should tell us something about the political, judicial, and popular resistance to the reforming ethos in punishment. In the postwar struggle to lay the ax once and for all to the gallows tree, a struggle that, as James Christoph affirmed, "cut more deeply into British life . . . than at any time since the first two decades of the nineteenth century," we have one of the more instructive moments in the history of modern British penology. ${ }^{12}$

10. See Harold L. Smith, ed., Britain in the Second World War (Manchester: Manchester University Press, 1996), 16-18; Terence Morris, Crime and Criminal Justice since 1945 (Oxford: Basil Blackwell, 1989), 34-37, 96 (table 7.2). For the concept of the moral panic, see Stanley Cohen, Folk Devils and Moral Panics: The Creation of the Mods and Rockers (London: MacGibbon and Kee, 1972). See also, Stanley Cohen and Jock Young, eds., The Manufacture of News: Social Problems, Deviance, and the Mass Media (Beverly Hills: Sage Publications, 1973).

11. Orwell contrasted the "domestic poisoning dramas" of the prewar era with the cause celebre of the war years, the Cleft Chin Murder, in which an American army deserter and an eighteen-year-old ex-waitress murdered a taxi driver with $£ 8$ in his pocket. "The background," explained Orwell, "was not domesticity, but the anonymous life of the dance-halls and the false values of the American film." See "Decline of the English Murder," in George Orwell, Decline of the English Murder and Other Essays (Harmondsworth: Penguin Books, 1965), 12. Of course, Orwell had a penchant for drawing a contrast between the ordered stability of the past and the awfulness of the present. See also Harry Hopkins, The New Look: A Social History of the Forties and Fifties in Britain (London: Secker and Warburg, 1963), 207-8; Peter Hennessy, Never Again: Britain, 1945-5I (New York: Pantheon Books, 1994), $445-46$.

12. James B. Christoph, Capital Punishment and British Politics (London: George Allen and Unwin, 1962), 190. I readily concede that a full measurement of the last point would require a broad-ranging penological and cultural analysis. I am currently preparing such a study, under the provisional title, The Rise and Demise of Rehabilitation: Punishment, Culture and Society in Modern Britain. 
In February 1810, Sir Samuel Romilly addressed the House of Commons on the subject of the frequency of capital punishment. "[T] country on the face of the earth," he declared, "in which there [have] been so many different offences according to law to be punished with death as in England."'13 In Romilly's day, there were some 220 capital offenses. Every felony, with the exception of petty larceny and maiming, was capital. As Fowell Buxton reminded the Commons in 1821, "the law of England has displayed no unnecessary nicety, in apportioning the punishments of death. ... Kill your father, or catch a rabbit in a warren-the penalty is the same! Destroy three kingdoms, or destroy a hop-bine-the penalty is the same!"14 The Bloody Code, as it was known, provided the most extensive capital jurisdiction in Europe. Only a small and declining proportion of those capitally condemned were actually executed, thanks to the regular use of the prerogative of mercy, but this only induced reformers like Romilly to assert that the nonexecution of the law was not the best way to mitigate the law's severity. The reformers pressed, instead, to exempt from capital punishment as many offenses as possible. This alone, they argued, would improve the detection, conviction, and punishment of delinquents. A stubborn rearguard action by the main representatives of ancien régime justice-Lord Chief Justice Ellenborough and Lord Chancellor Eldonslowed the amelioration of the penal code, but limb after limb of the Fatal Tree dropped away. ${ }^{15}$ At Victoria's accession in 1837, the number of capital crimes had fallen to fifteen, and over the next twenty-five years the

13. Parl. Deb., Commons, 15, Feb. 9, 1810, 366. The history of capital punishment has attracted considerable attention in recent decades. For the most important contributions, see Leon Radzinowicz, A History of English Criminal Law and Its Administration from 1750, vols. 1-4 (London: Stevens and Sons, 1948-1968); Douglas Hay et al., eds., Albion's Fatal Tree (London: Allen Lane, 1975); E. P. Thompson, Whigs and Hunters: The Origins of the Black Act (London: Allen Lane, 1975); J. M. Beattie, Crime and the Courts in England, 1660-1800 (Princeton: Princeton University Press, 1986); Peter Linebaugh, The London Hanged (London: Allen Lane, 1991); V. A. C. Gatrell, The Hanging Tree: Execution and the English People, 1770-1868 (Oxford: Oxford University Press, 1994). See also Elizabeth O. Tuttle, The Crusade against Capital Punishment in Great Britain (London: Stevens and Sons, 1961), 3-13; Potter, Hanging in Judgment, chaps. 1-3; B. P. Block and John Hostettler, Hanging in the Balance: A History of the Abolition of Capital Punishment in Britain (Winchester: Waterside Press, 1997), chaps. 1-4.

14. Parl. Deb., Commons, 5, May 23, 1821, 904.

15. See Gerald Gardiner and Nigel Curtis-Raleigh, "The Judicial Attitude to Penal Reform," Law Quarterly Review 65 (1949): 199-205; Derek Beales, "Peel, Russell and Reform," Historical Journal 17 (1974): 873-82; Boyd Hilton, "The Gallows and Mr Peel," in History and Biography: Essays in Honour of Derek Beales, ed. T. C. W. Blanning and David Cannadine (Cambridge: Cambridge University Press, 1996), 88-112. 
remaining capital offenses were reduced to the four that came down to the twentieth century. Just the trunk of the gallow's tree was left, on which alone was strung the murderer.

The succeeding phase in the crusade against capital punishment was much less effective. For abolitionists, the next fifty years were fallow ones, though they did have their moments. In 1866, the Royal Commission on Capital Punishment unanimously recommended a gradation of murder, by which many homicides then punishable by death would become noncapital, and five of the twelve Commissioners even declared themselves in favor of total abolition. No progress was made toward the establishment of degrees of murder, but an amendment to the 1868 bill providing for private executions proposed abolition. The amendment failed, at least in part because of the powerful defense of the death penalty, "when confined to atrocious cases," by renowned liberal John Stuart Mill, who argued that "the short pang of a rapid death" was a less cruel way of deterring the criminal from crime than "immuring him in a living tomb." 6 For the rest of the century, parliamentary bills were introduced to establish degrees of murder, but the difficulty of defining which murderers deserved death and which did not proved insuperable. Bills also continued to press for abolition but the opportunity had passed. The creation of the Court of Criminal Appeal in 1907, by diminishing the possibility of a fatal miscarriage of justice, further weakened the abolitionist case against the irrevocable nature of the death penalty. ${ }^{17}$ The revival of the abolitionist cause had to wait until after the First World War.

In the early 1920s, a succession of sensational murder trials and executions focused public attention on the question of capital punishment. One such was the execution of Edith Thompson in January 1923 for alleged complicity in the murder of her husband by her lover. Many felt she was hanged for adultery as much as for murder; and rumors began to circulate that she had gone to the scaffold in a state of semicollapse. The governor and chaplain of Holloway prison were both deeply distressed by this harrowing execution, and the executioner attempted suicide a fortnight later. Simultaneously, weeklies like the Spectator began to acknowledge that "public opinion has for some time been inclining against the death penalty." 18 The public seemed disturbed by the irrevocability of the death penalty and es-

16. See E. Roy Calvert, The Death Penalty Enquiry (London: Victor Gollancz, 1931), 3; Tuttle, Crusade, 17-20; Hollis, Homicide Act, 13; Parl. Deb., Commons, 191, Apr. 21, 1868, 1049.

17. See Rose, Struggle, 27-28; Potter, Hanging in Judgment, chap. 8; Public Record Office (hereafter PRO), Home Office (hereafter HO) 45/12914/154425/9.

18. See Potter, Hanging in Judgment, 121; Block and Hostettler, Hanging in the Balance, 86-88; Spectator, Jan. 13, 1923, 46. See also Justice of the Peace, Sept. 6, 1924, 536. 
pecially by the idea of hanging women. Significantly, in 1922, the Infanticide Act had reduced the penalty for women who killed their "newly-born" from murder to manslaughter, thereby ending the "black cap folly" of judges pronouncing the death sentence on women on whom all knew the sentence would not be executed. The last and most critical ingredient for a renewed abolitionist campaign was the addition of the Labour Party. From this point on, indeed, the movement for the abolition of capital punishment became closely associated with the British labor movement.

In 1923, the annual conference of the Labour Party passed a resolution urging the party to secure "the substitution of reformative treatment instead of the punitive treatment of criminals at present obtaining and the abolition of the death penalty." Soon letters urging abolition were pouring into the Home Office from local Labour Party branches and Labour Churches. ${ }^{19}$ Then, in January 1924, Labour was asked and agreed to form a ministry, though the party was in a minority in the House of Commons. According to the Howard League for Penal Reform (established in 1921), over one hundred M.P.s in the new Parliament, or one-sixth of the entire body, were in favor of abolition. Unfortunately, the first Labour government, which survived only until the autumn, did nothing for abolition. Home Secretary Henderson had intended to submit a memorandum to the cabinet on the question of capital punishment and was ready in February 1924 to tell the House that he would soon define the government's attitude. The prime minister, James Ramsay MacDonald, would have none of this. His office informed Henderson: "the Government cannot, within the first few months, commit themselves to every desire they have." ${ }^{20}$ As a result, two private member's bills failed to make progress, and the March deputation of the Howard League, led by Labour stalwart George Lansbury, was fed the standard Home Office line: abolition had never commanded a majority in any Parliamentary division, there was little evidence of any public desire for abolition, and there was no feasible substitute for capital punishment. All Henderson added by way of encouragement was: "You must agitate public opinion. You must get it on your side. You must raise in the House of Commons an interest which becomes compelling."21

The result of the first Labour government was to demonstrate the need for a central abolitionist body, capable of conducting a concerted campaign over an extended period. In 1925, the National Council for the Abolition

19. Labour Party Conference Report, 1923 (London: Labour Party, 1923), 250; HO 45 / $12914 / 154425 / 28,31$ and 32.

20. Howard Journal 1 (1924): 114; HO 45/12914/154425/57. The home secretary told the House, therefore, that the government had come to no decision on the subject: Parl. Deb., 5th ser., Commons, 170, Feb. 25, 1924, 84.

21. HO 45/19044/455787/31; Times, Mar. 25, 1924, 11 ; Howard Journal 1 (1925): 191. 
of the Death Penalty (NCADP) was established, with Roy Calvert as secretary. Calvert was the complete abolitionist, combining passionate commitment, moral earnestness, and scientific rigor. "My purpose is not a sentimental one," he wrote in Capital Punishment in the Twentieth Century (1927) - the classic statement of the case for abolition; "[m]y objection to the death penalty is based upon the conviction that it is both futile and immoral."22 It was Calvert's wife, however, who most accurately evoked his modus operandi: "He wished to see a general advance to an enlightened and rational humanity in the treatment of all law breakers, and viewing the campaign with the eye of a strategist he saw the Death Penalty as the stranglehold which enabled the forces of reaction to keep their ground." ${ }^{23}$ For the rest of the decade, the NCADP held hundreds of meetings on capital punishment around the country, circulated thousands of leaflets and pamphlets, and orchestrated countless parliamentary questions. Ties with the labour movement were understandably close. In early 1927 , a proabolitionist manifesto, signed by twenty-six Labour leaders and sent to 7,000 Labour Party branches and kindred bodies, helped to bring the issue before the party's rank and file. In late 1928, the bill to abolish capital punishment, sponsored by the NCADP, which was read for a first time in the Commons, was supported by most of the Labour leadership, including J. R. Clynes, the next Labour home secretary. This was the first occasion, moreover, on which Parliament had voted against capital punishment, albeit by a margin of one (119 to 118$).{ }^{24}$ Also in the course of the $1920 \mathrm{~s}$, a campaign orchestrated by Labour and Liberal M.P.s, including future Labour Prime Minister Clement Attlee, succeeded in abolishing the death penalty for military offenses (except for treachery, mutiny, and desertion to the enemy). ${ }^{25}$

The interwar peak of the abolitionist campaign was reached in October 1929 with the first full-scale debate in the twentieth century on the abolition of the death penalty, culminating in the appointment of the Select Committee on Capital Punishment. The precondition of this ascent was the elec-

22. E. Roy Calvert, Capital Punishment in the Twentieth Century (London: G. P. Putnam's, 1927), preface to the first edition. For Calvert, see Rose, Struggle, 203-5.

23. Foreword to Calvert, Capital Punishment, 5th ed. (1936), quoted in E. H. Jones, Margery Fry (London: Oxford University Press, 1966), 124.

24. Howard Journal 2 (1927): 124; Second Annual Report of the NCADP (1926-27), 3; Parl. Deb., 5th ser., Commons, 223, Dec. 5, 1928, 1220-26; Fourth Annual Report of the NCADP (1928-29), 4. This vote was of no practical import, since the majority in favor of abolition was too small to persuade the government to give the necessary parliamentary time for the remaining stages of the bill.

25. See Davies, "Power of Life and Death," 349-51; J. H. Brookshire, Clement Attlee (Manchester: Manchester University Press, 1995), 155. This campaign is described more fully in John McHugh, "The Labour Party and the Parliamentary Campaign to Abolish the Military Death Penalty, 1919-1930," Historical Journal 42 (1999): 233-49. 
tion of a new House of Commons in 1929, believed by the NCADP to contain a "substantial abolitionist majority," and of a new Labour ministry, with a home secretary, J. R. Clynes, who was thought to be "personally sympathetic" to abolition. In late October 1929, William Brown presented a motion in the House of Commons for abolition. Home Secretary Clynes immediately indicated that even if the motion passed, no bill would be introduced by the government until after a committee of inquiry. Brown reluctantly accepted Sir Herbert Samuel's amendment for the appointment of a Select Committee. ${ }^{26}$ Abolitionists were bewildered and for long believed that the resolution against capital punishment would have been carried by the House, had not Clynes and Samuel muddied the water. ${ }^{27}$ But they were soon mobilizing to win the argument before the Select Committee.

The committee consisted of members of the different parties in proportion to their strength in the House: seven Labour, six Conservative, and two Liberal M.P.s. All the Conservative representatives held retentionist views, even though possibly as many as a quarter to a third of all Conservative M.P.s were of abolitionist persuasion. Of the thirty-one British witnesses who gave evidence, ten advocated abolition, thirteen retention, and eight favored a reduction in the number of death sentences and executions. Pointedly, the committee refused to hear from the judges because their opposition to reform was a foregone conclusion..$^{28}$ Of the twenty-three acting or retired government officials to give evidence, only four favored abolition. Sir Alexander Paterson, the most reform-minded of the Prison Commissioners, was not among them. Echoing John Stuart Mill's speech, Paterson gave it as his opinion that death was more humane than the "rotting death" of a long prison term, though this hardly squared with his other main point, that six out of every seven persons sentenced to death should be reprieved, given that the average term served by a man undergoing life imprisonment was then over thirteen years. The primary fact that emerged from the enquiry was that abolition had been successful in the European countries that had tried it. ${ }^{29}$ Unfortunately, however, the committee divid-

26. Fourth Annual Report of the NCADP (1928-29), 5; A. Fenner Brockway to J. R. Clynes, June 28, 1929, in HO 144/19045/455787/71; Howard League executive committee meeting, July 12, 1929, Howard League Minute Books, MSS 16B/1/1, Modern Records Centre, Warwick University Library; Parl. Deb., 5th ser., Commons, 231, Oct. 30, 1929, 24166.

27. See E. Roy Calvert to J. R. Clynes, May 12, 1931, in HO 45/15739/546977/36. Cf. Law Journal 68 (1929): 284.

28. See Calvert, Death Penalty Enquiry, 11; Hollis, Homicide Act, 14-15; Select Committee on Capital Punishment, P.P., 1930-31, VI (15), Report, 1-99; Arthur Koestler, Reflections on Hanging (New York: Macmillan, 1957), 26.

29. Calvert, Death Penalty Enquiry, 27; Hollis, Homicide Act, 103. The abolitionist countries were Belgium, Denmark, Holland, Italy, Norway, Sweden, and Switzerland. See Calvert, Death Penalty Enquiry, 109. 
ed on strictly party lines, the Conservatives refusing to accept the final report. The Labour majority reported against the possibility of grading murders into two or more degrees and instead proposed the total suspension of capital punishment for a trial period of five years. Abolitionists hailed the result as the first recommendation by a public committee that the death penalty should be abolished; but the press, the opposition, and the Home Office all argued that the report was not representative of the views of its members. The Labour government, before it fell in August 1931 , consistently refused to grant time for the Commons to discuss the report, though Clynes himself never wished to block debate on the subject. ${ }^{30}$

In the thirties, opinion in favor of abolition continued to ripen. An influential advocate was the archbishop of York, William Temple, a member of both the NCADP and the Labour Party, and a rare example of a Church of England leader willing to declare for abolition. Temple had impressed upon the 1930 Select Committee that capital punishment devalued rather than sanctified human life. In 1935 he wrote an essay on the death penalty, subsequently reprinted in pamphlet form by the NCADP, in which he insisted that the debate over the death penalty had an importance that went beyond the subject itself. Retention or abolition, he said, "must depend upon the moral principles accepted by the community for the government of its penal code." He concluded by declaring that "few public actions would at the present time so much demonstrate and secure an advance in the ethics of civilization as the abolition of the Death Penalty." The archbishop also believed that public opinion, in many cases, was against the execution of criminals. The barrister Gerald Gardiner was similarly convinced that, since the publication of the evidence given before the Select Committee, "there has been a marked change of opinion among the members of the Bar," though Lord Chief Justice Hewart remained adamantly retentionist. ${ }^{31}$ In response, perhaps, to the state of public opinion, the proportion of reprieves increased steadily. In the years on either side of the thirties, 60 percent of those sentenced to death were executed; between

30. See HO 45/17481/584763/16; HO 45/15739/546977/32. In the mid-1930s, the Labour Party Conference passed a resolution, introduced by renowned suffragist Frederick PethickLawrence, that urged the next Labour government to give legislative effect to the Select Committee's recommendation for the abolition of the death penalty.

31. The Archbishop of York, "The Death Penalty," Spectator, Jan. 25, 1935, 112; Tuttle, Crusade, 49; Potter, Hanging in Judgment, chap. 11. Temple was made archbishop of Canterbury in 1942. His death in 1944 prevented his involvement in the postwar debate over the death penalty. His successor, Geoffrey Fisher, was cut from a different cloth. See also G. Gardiner to Sir John Gilmour, April 16, 1935, in HO 45/17481/584763/21B; Lord Hewart, "The Sentence of Death. Why It Still Remains a Necessity," News of the World, cutting in HO 45/17481/584763/27A. 
1930 and 1939 , the figure fell to 43 percent. Moreover, the average of 8.2 executions each year in the thirties was the lowest of any decade in the twentieth century. ${ }^{32}$

There was another important way of developing parliamentary opinion. Every Wednesday in the House of Commons backbenchers could make private members' motions. The government was not bound by the result, but since the "whips" were not on, M.P.s could vote without the restraint of party loyalty. In November 1938, Conservative M.P. Vyvyan Adams, who was also a member of the executive committee of the NCADP, tried his hand with a motion welcoming legislation to abolish the death penalty for five years. He launched the first full-scale Commons debate on capital punishment since 1929. The undersecretary of state at the Home Office, Geoffrey Lloyd, opposed the motion on the grounds that the experimental period was too short to enable the effect of abolition to be measured; that the difficulties involved in an alternative penalty would not reveal themselves in a five year period; and that opinion in favor of abolition had not increased. Even so, the division (ayes 114, noes 89 ) showed a majority in favor of the legislation. Among the abolitionists were ten future Labour ministers, including James Chuter Ede, home secretary in the postwar Labour government. But the present National Government, led by Conservative Prime Minister Neville Chamberlain, refused to embrace the principle of abolition, contending that since the resolution was passed in a thinly attended House on a private members' day, it expressed the view neither of the House nor of the country on this question. ${ }^{33}$

Fortunately for the abolitionists, another opportunity arose within the year. The Conservative politician, Sir Samuel Hoare, whose great-grandfather had been an abolitionist in Romilly's time, insisted on going to the Home Office in May 1937 in order to advance the cause of penal reform. He wished to introduce legislation that would incorporate the findings of several committees (namely those on young and persistent offenders and on corporal punishment) and the ideas of Prison Commissioner Sir Alexander Paterson. As for the death penalty, Hoare later recorded: "I was instinctively drawn towards the total removal from the Statute Book of a punishment that was altogether out of keeping with the kind of penal reforms that I had at heart." Alas, he also believed that to avoid a controversy that might endanger the rest of the Criminal Justice Bill, he had to exclude a clause to abolish the death penalty. The issue, he maintained, needed

32. See Parl. Deb., 5th ser., Commons, 416, Nov. 29, 1945, 1753-54.

33. Parl. Deb., 5th ser., Commons, 341, Nov. 16, 1938, 954-1012. The other abolitionists who became Labour ministers included A. V. Alexander, Aneurin Bevan, James Griffiths, F. W. Pethick-Lawrence, Emanuel Shinwell, and Joseph Westwood. See also HO 45/18066/ $677344 / 34$. 
a separate bill upon which Parliament could come to a decision. The heated exchanges on the abolition of corporal punishment, which the House of Lords would have opposed had the war not intervened, give some credence to Hoare's position. The abolitionists still saw a chance, however, of raising the issue. When the Criminal Justice Bill was under consideration in standing committee in the spring of 1939, a new clause was presented proposing abolition for a five year period. In view of Home Secretary Hoare's opposition, the committee rejected the new clause. ${ }^{34}$ When war broke out a few months later, criminal justice reform was by consent shelved until after the war.

An abolitionist balance sheet of the interwar years would have to include both debit and credit entries. The grand prize had certainly eluded them, despite the best efforts of a new abolitionist body and campaign and the support of one of the two main political parties in Parliament. A worrying trend was already evident, moreover, for Labour's leadership tended to be more enthusiastic abolitionists when in opposition than when in government. In office, Labour seemed more concerned to follow parliamentary opinion than to lead it. Nonetheless, abolitionists could take heart from the Report of the Select Committee, which demonstrated that capital punishment could be successfully relinquished in Britain, as it had been in much of western Europe. Public opinion was also surely moving towards abolition. In a November 1938 Gallup poll, to the question "Should the death penalty be abolished?" 45 percent of those who held an opinion answered Yes, 55 percent said No, while 11 percent expressed no opinion. Furthermore, executions were becoming rare events. Even J. S. Mill had accepted that if the time came when home secretaries, "under pressure of deputations and memorials," shrank from their duty, "and the threat becomes ... a mere brutum fulmen; then, indeed, it may become necessary ... to abrogate the penalty." 35 And there was yet another straw in the wind: abolition of capital punishment now ran in tandem with the movement to carry through long-needed reforms in criminal law and its administration. Indeed, the abolition of the death penalty became for many penal reformers a deeply symbolic test of the country's commitment to the reformative treatment of prisoners.

Whichever party had been in power in 1945 would have been obliged to introduce a Criminal Justice Bill. The reformers were doubtless hoping, however, that Labour would be in government, and for good reasons. As

34. Viscount Templewood (Samuel J. G. Hoare), The Shadow of the Gallows (London: Victor Gollancz, 1951), 10; Bailey, Delinquency, 143-46; Hollis, Homicide Act, 15.

35. George H. Gallup, ed., The Gallup International Public Opinion Polls: Great Britain, 1937-75 (New York: Random House, 1976), 1:11; Parl. Deb., Commons, 191, April 21, 1868,1051 . 
early as 1942, when the war was far from over, Herbert Morrison, socialist home secretary in the Coalition Government, considered appointing a committee on the reformative treatment of prisoners. He turned for advice to the political scientist, and member of the Labour Party's National Executive Committee, Harold Laski. The latter submitted a strident report on behalf of a Royal Commission to create an effective public opinion in favor of a Criminal Justice Bill. He drew attention to the "painfully small part played by the judges in the reform of the Criminal Law" and to their hostility to "the revision of penal concepts in the light of advancing medical knowledge." Consequently, Laski warned against a commission with a judge as chair "and a flock of barristers and solicitors among its members." ${ }^{36}$ In the event, the idea of a Royal Commission was superseded by the appointment of the Advisory Council on the Treatment of Offenders, with a particular brief to examine juvenile delinquency. But this did nothing to diminish Morrison's desire to prepare for legislation. In April 1944, he asked Prime Minister Winston Churchill if he could reintroduce the Criminal Justice Bill. Though Churchill advised waiting on the subject, Morrison stood firm, asking again to "stake out a claim for a Penal Reform Bill in our legislative programme of social reconstruction after the war." 37 The issue would not brook postponement, he insisted; all the penal reform groups, at war's end, would press the government to reintroduce the Criminal Justice Bill.

A year later, the war was over, and a Labour government had indeed been elected, with a majority of 146 over all other parties (393 M.P.s out of 640). Britain now became a laboratory of social engineering. Over one-fifth of the economy was taken into public ownership; the framework of the welfare state was erected. "Not since the Washington of the early New Deal in 1933," declared historian Ken Morgan, "had the governmental agencies in a democratic country been so caught up in experimentation and social advance." ${ }^{38}$ The socialist tide flowed strongly until mid-1947, when economic problems and a reinvigorated Conservative opposition forced Labour to retrench. For three years, however, the country had witnessed a torrent of reformist legislation. The condition of criminal justice, moreover, was an integral part of this postwar reform program.

James Chuter Ede, the new home secretary, had the task of winning a place for penal reform in the program of reconstruction. In April 1946, he decided to introduce the Criminal Justice Bill of 1938, subject to a few

36. June 13, 1942, in HO 45/21948/884452/1. For Laski, see K. O. Morgan, Labour People (Oxford: Oxford University Press, 1987), 91-100.

37. See Bailey, Delinquency, 287-89; HO 45/21948/884452/1.

38. K. O. Morgan, The People's Peace: British History, 1945-1990 (Oxford: Oxford University Press, 1992), 30. 
modifications. At the legislation committee in early July, however, Ede was asked by Herbert Morrison, leader of the House of Commons, to withdraw the bill until the next session. Ede declined, warning that the government "would be exposed to criticism if they concentrated entirely on economic measures and did not include ... some social and humanitarian measures." Two days later, Ede informed the permanent secretary at the Home Office that the bill was safe. In fact, it was not. In October 1946, Morrison again asked Ede to omit the Criminal Justice Bill from the 1946-47 legislative program, and he was forced to comply. ${ }^{39}$

At this point, it was still an open question whether a provision to abolish or suspend the death penalty would get into the new bill. It is to this issue we now turn. The goal is to explain the Labour government's conduct in the lead up to the Second Reading of the Criminal Justice Bill in November 1947, by which time the government had decided to omit an abolitionist clause from the bill, but to allow a free vote in the House of Commons if an abolitionist amendment were introduced. ${ }^{40}$

\section{II}

In March 1947, the pace quickened. Morrison asked Chuter Ede to submit a policy paper on the Criminal Justice Bill. Of most significance, for present purposes, is the home secretary's view that any amendment to abolish or suspend capital punishment "should be resisted on the ground that it is inappropriate that such a far-reaching change in the law should be included in a Criminal Justice Bill, and that, if any such change in the law were to be effected it should be after full consideration in a separate Bill deal-

39. HO 45/21950/884452/75 and 77. The press and penal reform lobby felt that a scheme of penal reform deserved a place in Labour's program. See Times, Mar. 12, 1946, 5 and HO 45/21951/884452/99.

40. In this task I have been helped by Gordon Rose, Elizabeth Tuttle, and James Christoph, all of whom, in the early 1960s, examined the Labour government's contribution to the movement to abolish the death penalty. See Rose, Struggle; Tuttle, Crusade; Christoph, Capital Punishment. They did so, however, before the cabinet and other official papers were available for public scrutiny. More recently, Lord Windlesham used a few of the relevant official papers in his study of penal policy making. See Windlesham, Responses to Crime, vol. 2, Penal Policy in the Making (Oxford: Oxford University Press, 1993), chap. 2. And Sir Leon Radzinowicz reviewed the lead-up to the Royal Commission on Capital Punishment, 1949-53, of which he was a member, but without any special inquiry into the main questions. See Radzinowicz, Adventures in Criminology (London: Routledge, 1999), 24552. It seems worthwhile, therefore, to return to this ground in the light of the available cabinet papers, of Home Office and Lord Chancellor's Office papers, and of the memoirs of some of the main political personalities. 
ing solely with this subject." At the Lord President's Committee meeting held on March 7, therefore, Chuter Ede remarked that most controversy was likely to center on the abolition of corporal punishment. ${ }^{41}$

Indeed, the main dispute that broke out between Home Secretary Ede and Lord Chancellor Jowitt was over corporal punishment. Ede stood his ground, reminding the meeting that on the matter of abolishing corporal punishment, "the Labour Party were deeply committed by their attitude in 1938." 42 He had an ally in the attorney-general, Sir Hartley Shawcross, who said he strongly supported the abolition of corporal punishment. Additionally, Shawcross argued that the bill should provide also for the abolition or suspension of the death penalty and that "[t]he attitude of the Bench to past proposals for the reform of the criminal law did not suggest that their judgment in this matter was reliable," a brave line from a young government law officer. ${ }^{43}$ Even so, Lord Chancellor Jowitt was invited to put his

41. HO 45/21951/884452/99; "Criminal Justice Bill," memo by Home Secretary, Mar. 2, 1947, Lord President's Committee (hereafter L.P.) (47) 39, attached to Cabinet Papers (hereafter C.P.) (47) 182, June 16, 1947, PRO, Cabinet Office (hereafter CAB) 129/19. The lord chief justice, Lord Goddard (appointed by Prime Minister Attlee in January 1946), had already informed the home secretary that he and two of his fellow judges did not agree that corporal punishment should be entirely abolished. Goddard to Ede, Nov. 28, 1946, HO 45/ $21951 / 884452 / 86$. The lord chancellor, Lord Jowitt, had said much the same to the attorney-general, Sir Hartley Shawcross: "I am one of these old-fashioned people who believe in corporal punishment though I would abolish the Cat. I would be very sorry to see the birch or the cane disappear." PRO, Lord Chancellor's Office (hereafter LCO) 2/3340. The Lord President's Committee was a sub-cabinet or general purposes committee; it had referred to it questions of domestic policy not assigned to other committees. See Herbert Morrison, Government and Parliament (Oxford: Oxford University Press, 1954).

42. L.P. (47) 8th meeting, Mar. 7, 1947, CAB 132/6. In the 1930s, the birching of young offenders (to whom corporal punishment was effectively restricted) had been almost abandoned by the courts. The wartime rise in delinquency, however, led to renewed birching, at least until 1943, when a controversial case in the Hereford juvenile court again deterred courts from ordering the birch. See Rose, Struggle, 213; Geoffrey Pearson, Hooligan: A History of Respectable Fears (London: Macmillan, 1983), 261, n. 92.

43. Ibid. The attorney-and solicitor-general were the chief legal advisers to the executive. The attorney-general was not a member of the cabinet, but he saw all the relevant cabinet papers, and he would attend cabinet meetings to advise upon legal or constitutional issues. See J. Ll. J. Edwards, The Law Officers of the Crown (London: Sweet and Maxwell, 1964), 174-75, and chap. 9, passim. The position of lord chancellor was something of a constitutional oddity. He participated in all three branches of government: as cabinet minister, speaker of the house of lords, and head of the judiciary. See John Griffith, Judicial Politics since 1920 (Oxford: Basil Blackwell, 1993), 65. The Labour Party was congenitally distrustful of the senior judiciary and legal profession. This was only intensified by the mistrust of Lord Chancellor Jowitt by the more left-wing members of the Labour government (notably Nye Bevan). The fact that Jowitt boasted in late 1947 that he had never appointed "a member of my own Party" to be a judge corroborated the doubts about Jowitt, which had their origin in his thin socialist credentials. He generally took a detached attitude to cabinet quarrels and party- 
reservations on paper and allowed to consult the lord chief justice and certain other senior judges about the proposals. ${ }^{44}$

The exchange of views at the meeting of the Lord President's Committee also spurred the law officers into action. In early April 1947, Shawcross and Sir Frank Soskice (the solicitor-general) sent a strongly worded statement to both Jowitt and Chuter Ede. The proposed abolition of flogging, the law officers proclaimed, "carries out what has always been Labour Party policy." Corporal punishment had neither deterrent value nor reformative effect. "There are," they continued, "the strongest moral objections to its use as barbarous and degrading to society." They took the same view about capital punishment:

If, as it is agreed, the present Bill provides a suitable opportunity for the abolition of flogging, we can see no reason why it should not be equally appropriate for the abolition of capital punishment if the abolition of such punishment is otherwise desirable. We do not think that the Labour Party in the House would be likely to accept the position that this matter could not be dealt with in the present Bill unless an assurance were given that special legislation would be introduced. The case in favour of abolition of capital punishment seems to us overwhelming and the grounds for its abolition very similar to those above urged for the abolition of flogging.

Moving to a loftier moral plane, they wrote feelingly:

The knowledge that society is deliberately hunting a man to his death, and when it has caught him taking away his life with the hideous trappings of legal execution, cannot fail to lessen the respect for the sanctity of human life.... It is absolutely no answer to say that the convicted man has himself taken human life, since by carrying out the act of execution society is rendering itself culpable of precisely the same act as that for which the condemned man has been convicted.

political questions. See Robert Stevens, Law and Politics: The House of Lords as a Judicial Body, 1800-1976 (Chapel Hill: University of North Carolina Press, 1978), 336-37, and The Independence of the Judiciary (Oxford: Oxford University Press, 1993), 78-79, 114; "Message from Britain: The Lord Chancellor's Address in Cleveland," American Bar Association Joumal 33 (1947): 1180.

44. Jowitt was persuaded that corporal punishment had a deterrent effect and that judges should have the increased power to inflict corporal punishment "in all cases involving violence, particularly where women and children are concerned." See Jowitt to Lord Chief Justice, Mar. 7, 1947, LCO 2/3340; Jowitt to Ede, Mar. 28, 1947, HO 45/21951/884452/99. The lord chancellor's correspondence also reveals that he had doubts about other provisions of the Criminal Justice Bill concerning young offenders, believing that they were unduly lenient. Above all, he thought the middle of a crime wave was not the moment to shout from the housetops that juvenile criminals could not be whipped. 
They strongly urged, therefore, that the opportunity be taken in the bill to give effect to "what has been for many years a humanitarian conception associated with the Labour movement. There can, we think, be no excuse for what is virtually a running away from an obvious opportunity to introduce this overdue reform." The law officers had firmly nailed their colors to the mast. In his cover letter, Shawcross added that strong views were held in the party on corporal and capital punishment and the government could be defeated if they opposed abolition, with the whips on. ${ }^{45}$

In May 1947, the Criminal Justice Bill was slotted for the 1947-48 session. The abolitionists were relieved, since it would allow time in the present Parliament to override a veto of the House of Lords, which a later date would not have done. The Lords still had the power to delay a bill's passage for two years (though the government had plans to abbreviate their delaying power). The cabinet now had to resolve how they wished to deal with corporal and capital punishment. At the cabinet meeting of June 19, Ede refused to give way on the flogging issue, and Jowitt finally conceded that "for political reasons it would be very difficult to do less than had been proposed in the Bill introduced in 1938. ${ }^{{ }^{46}}$ On the desirability of abolishing the death penalty, ministers were divided. Retentionists (Morrison undoubtedly, Ede and Jowitt presumably) argued that public opinion was

45. Shawcross had been associated with the Howard League for Penal Reform in the 1920s and had been a member of the Advisory Council on the Treatment of Offenders, the body established in August 1944 by Herbert Morrison, when home secretary, to plan postwar penal reform. See New Statesman, Feb. 21, 1975, 234-36; Bailey, Delinquency, 288. Shawcross had always opposed capital punishment, but in 1945-46, he acted as the chief British prosecutor at the Nuremberg trial. "So far as the Nazi war criminals were concerned," Shawcross wrote many years later, "I did feel that if ever the death sentence was deserved it was in most of the Nuremberg cases." See Shawcross, Life Sentence: The Memoirs of Lord Shawcross (London: Constable, 1995), 130. The citations in this and the previous paragraph are all drawn from HO 45/21951/884452/102B. See also Shawcross to Jowitt, Apr. 16, 1947, HO 45/21951/ $884452 / 102 B$. Jowitt replied to Shawcross on Apr. 19, 1947: "On corporal and capital punishment I have no doubt you are right in saying that strong views are held in the Party. I wonder how much thought and knowledge have gone to the formation of these views?" See LCO $2 /$ 3340. In an earlier letter to Shawcross, Jowitt had spoken to the issue of the death penalty: “. . . it may well be true that our Party would demand the abolition of capital punishment. I think they would be unwise in so doing, particularly at the present time. . . At least let us realise that if we are going to indulge in humanitarian conceptions we may expose the ordinary citizen to added peril." See Jowitt to Shawcross, Apr. 10, 1947, LCO 2/3340.

46. C.P. (47) 182, June 16, 1947, "Criminal Justice Bill," memo by Home Secretary, CAB 129/19; minute by F. Graham-Harrison, Assistant Private Secretary to the Prime Minister, June 18, 1947, Prime Minister's Private Office (hereafter PREM) 8/739; Cabinet Minutes (hereafter C.M.) (47) 55th conclusions, Cabinet meeting, June 19, 1947, CAB 128/10. At first, the cabinet was dominated by Attlee, the prime minister; Herbert Morrison, lord president and leader of the Commons; Ernest Bevin, foreign secretary; Hugh Dalton, chancellor of the exchequer; and Sir Stafford Cripps, president of the Board of Trade. 
not yet ready for abolition, that the abnormal amount of robbery with violence made abolition unwise, that the judges "were convinced that the fear of capital punishment was a real deterrent" and an effective alternative punishment was wanting, and that abolition at home would make it hard to justify its retention in the colonies and in the British Zone of Germany. Abolitionists (Shawcross indubitably, Aneurin Bevan most probably, and Shinwell possibly) argued that there was no firm evidence of its deterrent effect (particularly in the case of unpremeditated murders), that the opinion of His Majesty's judges was unreliable, and that the government supporters in Parliament who had studied the matter were unanimously in favor of abolition. In the face of such a divergence of opinion, the prime minister suggested that the cabinet return to the issue at a later meeting. ${ }^{47}$

For the next month, the Home Office worked on the question. The guiding light in these internal discussions was the permanent secretary, Sir Alexander Maxwell. He was particularly concerned about the parliamentary strategy that seemed to be evolving. The plan was to introduce the bill without a clause abolishing capital punishment. Then, in the Second Reading debate, the suggestion would be made that, since the question aroused differences of opinion transcending party lines, the government would leave the matter to a free vote of the entire House. (This would, in fact, be the course ultimately followed by the cabinet.) For Maxwell, pitfalls abounded on this path. "To leave the matter to a free vote of the House," he argued, "would be an indication that the Government had not made up its mind on the question." If an abolitionist clause was introduced on a free vote, this would only inspire the House of Lords to delete the clause from the bill and defend their action on the ground that the government had given no clear lead to Parliament. At that point, the government would feel unable to leave the matter any longer to a free vote and thus would have to decide "either to propose that [the] Lords amendment be rejected or to propose it be accepted and to put the Whips on." All this, it has to be said, bears an uncanny approximation to the difficulties that soon overtook the government.

Maxwell's main advice, therefore, was to take the bull by the horns. Unless the government was prepared to resist an amendment proposing abolition, however strong its supporters in the Commons, "their right line would be to take the initiative and to insert in the Bill as introduced a Clause for the abolition of the death penalty. If the Government are going ultimate-

47. C.M. (47) 55th conclusions, Cabinet meeting, June 19, 1947, CAB 128/10. The prime minister was no partisan on the question of capital punishment, even though he had been involved in securing the abolition of the death penalty for military offenses (see text at note 25 above). For Attlee, I suspect, capital punishment was not a manifesto pledge, but a "policy novelty" for which he had little time. Compare Morgan, Labour People, 140. 
ly to accept a Clause to this effect, and to resist any attempt on the part of the House of Lords to delete it, their better course would be themselves to propose the Clause." 48 Maxwell's thinking imposed itself on the home secretary's July 8 memorandum for cabinet discussion. ${ }^{49}$

At the meeting of July 15,1947 , it became crystal clear that the cabinet was trapped in a logical circle of its own creation. The discussion went something like this. Since ministers could not agree on the merits of the question, the right course was to tell the Commons that because there were differences of opinion transcending party lines, the matter would be left to a free vote of the House. If this resulted in an abolitionist amendment, however, one that was accepted by the Commons but then rejected by the Lords, the government would be in an awkward position. There was much to be said, therefore, for uncoupling the death penalty question from the Criminal Justice Bill. But such was the sentiment in the House and Party that a quid pro quo of an uncoupling would be a government promise of abolitionist legislation in a later session. For this, ministers had to agree that the death penalty ought to be abolished. But this was exactly what ministers could not agree upon $!^{150}$

Not until early November 1947 did the cabinet return to the issue. It then learned from Herbert Morrison that his recent meeting with the Parliamentary Labour Party (P.L.P.) indicated that while government supporters would accept the absence in the bill of a provision for the abolition of capital punishment, they had every intention of moving an abolitionist amendment. The cabinet resolved that in these circumstances the decision on this issue should be left to a free vote. ${ }^{51}$ The next day the bill was published.

The main principle of the Criminal Justice Bill was warmly received by the press. "Modern penal doctrine," said the Times, "has firmly established that simple retribution . . . is not a proper objective of secular justice." "It is right," said the Daily Telegraph, "that no individual with the capacity for self-redemption should be denied an opportunity to re-qualify for the privileges and responsibilities of citizenship." There was less unanimity concerning the government's decision to omit an abolitionist clause. The Times

48. Minutes of June 25 and July 1, 1947, HO 45/21959/884452/203. By July 1947, the Parliamentary Penal Reform Group, organized by the Howard League, had got 187 (mostly Labour) M.P.s to sign a memorial to the home secretary asking him to include in the Criminal Justice Bill a provision to suspend the death penalty for a five-year experimental period. In addition, a joint deputation from the League and the NCADP met Home Secretary Ede and gained the impression that he had no firm views on the subject of capital punishment. See Christoph, Capital Punishment, 36-37; Morris, Criminal Justice, 79.

49. C.P. (47) 200, July 8, 1947, "Abolition of the Death Penalty," memo by Home Secretary, CAB $129 / 19$.

50. C.M. (47) 61 st conclusions, Cabinet meeting, July 15, 1947, CAB 128/10.

51. C.M. (47) 84th conclusions, Cabinet meeting, Nov. 3, 1947, CAB 128/10. 
inclined toward an abolitionist position. "Capital punishment is so repulsive that no civilized people would continue it unless convinced that there is no other means of protecting life." On the day of the bill's Second Reading, the same paper declared that the experiment of suspending capital punishment for five years "would provide both parties to the controversy ... with the facts required for a final settlement of their difference." Lord Templewood doubted the wisdom of retaining capital punishment. The "savage executions that have disgraced Europe have convinced me," he said, "that the time has come for us to give a conspicuous example of our detestation of brutal punishments." The secretary of the NCADP, Frank Dawtry, complained that the bill's intention to fit treatment to the criminal, not the crime, "will seem to be contradicted if the death penalty remains, for most murderers are first offenders." "Who could have imagined," said C. H. Rolph in the New Statesman, "that this immensely powerful Government, containing probably more idealists to the square vote than any of which there is biographical record, would reject the opportunity afforded by a great penal reform Bill to abolish the death penalty?"52

In the final days before the Second Reading debate, the cabinet made two more decisions: one, that the home secretary should advise the Commons that there would be serious risks in abolishing capital punishment in the unsettled conditions following a major war (which amounted to advising the House to reject the amendment abolishing the death penalty); and, two, that ministers who dissented from the government's advice should refrain from speaking in the debate, but should be free to vote according to their convictions. ${ }^{53}$

52. Times, Nov. 5, 1947; Daily Telegraph, Nov. 5, 1947; Times, Nov. 27, 1947; Observer, Nov. 9, 1947, press cuttings in HO 45/21953/884452/128B. Templewood (formerly Sir Samuel Hoare) was now president of the Howard League and a publicly proclaimed abolitionist. See also Manchester Guardian, Nov. 11, 1947, press cutting in HO 45/21962/884452/ 263; "Cat and Hangman," New Statesman, Nov. 15, 1947, 387.

53. C.P. (47) 306, Nov. 13, 1947, "Criminal Justice Bill: Capital Punishment," memo by Home Secretary, CAB 129/22; Norman Brook minute, Nov. 14, 1947, PREM 8/739; C.P. (47) 310, Nov. 17, 1947, "Criminal Justice Bill: Capital Punishment," memo by Secretary of State for Scotland, CAB 129/22. Norman Brook was the secretary of the cabinet. For Brook's influence, particularly through his "steering-briefs" for Attlee, see Peter Hennessy, Cabinet (Oxford: Basil Blackwell, 1986), 18. In Scotland, only eight death sentences were imposed in the fifteen years between 1929 and 1944. None was carried out. This situation was largely the result of the acceptance by the Scottish courts of a doctrine of diminished or impaired responsibility, which, if established, reduced the crime from murder to culpable homicide. Thus, by the attitude of the courts, and the exercise of the prerogative, the death penalty had been virtually abolished. And during this time crimes of violence did not increase. Nonetheless, the Scottish secretary, Arthur Woodburn, still felt the government should give a lead in favor of retaining the death penalty. See also C.M. (47) 89th conclusions, Cabinet meeting, Nov. 18, 1947, CAB 128/10; Norman Brook minute, Nov. 18, 1947, PREM 8/739. 
On November 27, 1947, the Second Reading of the Criminal Justice Bill took place. At the close of his speech, Home Secretary Ede stated the government's position on capital punishment. The reasons for retaining the death penalty were, first, that it acted as a deterrent; second, that the war and postwar rise in crime made it dangerous to experiment with abolition; and, third, that little public support existed for such an experiment. However, "recognising that this is a matter on which very strong individual conscientious feelings are held and that the division does not follow the usual party lines," the government, said Ede, would "leave the final decision to a free vote of the House," and "no attempt will be made to coerce the conscience of any individual hon. Member." (No one thought to ask whether this meant minister as well as backbencher.) For the opposition, Osbert Peake promised that any vote on capital punishment would be free on his side of the House also. He himself felt that capital punishment should be retained in view of the increases in violent crime, ending his speech with something of a non sequitur: "There were few protests, if any, about capital punishment at the time the Nuremberg Trials took place, and certain very depraved men were brought to a very proper end." 54

Sydney Silverman, a left-wing Labourite and outspoken leader of the abolitionists in Parliament, greeted the bill as "a great act of courage and a great act of faith," before noting caustically that the increase in violent crime had led the previous (Templewood) and present (Ede) home secretaries to change their minds about capital punishment in precisely opposite directions; and that the same increase led Ede to conclude that corporal punishment (inflicted in the main for violent crime) should be abolished, while capital punishment (for a crime known to be little affected by general crime waves) should be retained. These confusions aside, Silverman acknowledged that the government "have done wisely and generously, in agreeing to leave this matter to the free, unfettered, judgment of Members of the House." ${ }^{55}$ Otherwise, the Second Reading debate passed off without incident, and the crucial vote on the death penalty was postponed for several months.

54. Parl. Deb., 5th ser., Commons, 444, Nov. 27, 1947, 2150-51, 2161.

55. Ibid., 2186-89. Silverman made the obligatory abolitionist attack upon the judges, who "have always been on the side of harshness, cruelty, corporal punishment, and capital punishment," and "have always been demonstrably wrong" (2188). For Silverman, see Emrys Hughes, Sydney Silverman: Rebel in Parliament (London: Skilton, 1969), 90; Christoph, Capital Punishment, 42; Dictionary of National Biography, 1961-70 (Oxford: Oxford University Press, 1980), 941-44. Silverman was something of a thorn in the government's flesh. In October 1946, he had been a critic also of the government's foreign policy, believing it to be too pro-American. See Emanuel Shinwell, I've Lived Through It All (London: Victor Gollancz, 1973), 188. 
What conclusions can we draw from this recital of the government's conduct? There are, I would submit, five possible explanations for its behavior. The first is that given by the home secretary during the Second Reading debate: a cocktail of deterrence, public opinion, and crime rates. It has considerable validity. The senior judges, Lord Chancellor Jowitt, and Chuter Ede all subscribed to the deterrent efficacy of the death penalty. They also took notice of, and were not above exploiting, opinion polls that indicated there were at least two retentionists for every abolitionist. When a deputation from the NCADP came to see him in July 1947, Ede specifically asked for the council's view on the results of a recent Gallup Poll. ${ }^{56}$ And Ede and Jowitt were not alone in underlining the war and postwar crime rise. Indeed, it is arguable that the increase in recorded crime, interpreted by many as a sign of the erosion of traditional moral standards, did more than anything to turn back the tide of abolition and of penal reform in general. The recorded incidence of murders and crimes of violence was markedly higher than before the war. No longer was the rise in juvenile delinquency reassuringly ascribed to the willingness of police and public to use the reformed system of juvenile justice, as it had been in the 1930s, but rather, as even Lord Templewood insisted in February 1947, because "moral restraints have lost much of their power in the confused and restless world of today." 57 The moral crisis was aggravated in July by the trial of the three young men (aged 17, 20, and 23) who had shot Alec de Antiquis while robbing a south London jeweler's shop. All were found guilty of murder, and following unsuccessful appeals, the two eldest were executed on September 19, 1947. In a letter to the Times, three weeks before the Second Reading debate, Mr. Curtis-Bennett declared that to let such

56. July 7, 1947, HO 45/21959/884452. The Gallup Poll had asked: "In this country most people convicted of murder are sentenced to death. Do you agree with this or do you think that the death penalty should be abolished?" The result was: Agree, 69 percent; Abolish, 24 percent; No opinion, 7 percent. See Gallup, ed., Public Opinion Polls, 156. Abolitionists soon realized, as Koestler remarked, "that governments only use public opinion as a shield when it is convenient to them." When public opinion demanded reprieves, government could just as easily disregard it. See Koestler, Reflections, 164.

57. The number of indictable (or serious) offenses known to the police rose by 76 percent between 1938 and 1947. More specifically, the annual average of cases of murder (of persons aged over one year) increased from 95 between 1936 and 1939 to 121 between 1945 and 1948. Crimes of violence against the person (committed by persons aged seventeen and above) rose from 1,467 in 1938 to 2,952 in 1948 , or from 4.7 to 8.9 per 100,000 population. Indictable sexual offenses known to the police rose by 54 percent between 1945 and 1950. And the daily average prison population went up from close to 13,000 in 1944 to over 17,000 in 1947. Moreover, since the prevalence of crime had not yet been politicized, it could still infuence all the political parties. See Rose, Struggle, 215; Morris, Criminal Justice, 96. For the 1930s, see Bailey, Delinquency, chap. 5; Pearson, Hooligan, 46-47. For Templewood's lecture to the newly formed Department of Criminal Science in the School of Law, Cambridge University, see Times, Feb. 1, 1947. 
young men know "that they can still kill, and live, is surely madness and an invitation to murder." Tellingly, the 1947 Criminal Justice Bill, unlike the 1938 bill, provided for "detention centres," residential institutions in which the regime would be brisk and the sentence brief, in order to apply a "short, sharp shock" to young offenders. There seems little doubt that this new measure was a quid pro quo to appease a judiciary that resented being deprived of the power to order corporal punishment. ${ }^{58}$

There is evidence, too, for an explanation that emphasizes the desire not to lose the Criminal Justice Bill by including a clause that could arouse controversy. Like Sir Samuel Hoare in 1938, Ede and his officials did not want to endanger a bill that could improve the treatment of young and recidivist offenders, and a bill that had all-party support, by embroiling it in the contentious debate over the death penalty. Perhaps they thought that the proposal to deprive the courts of all power to impose flogging sentences would load the bill with as much controversy as it could carry in a session. Just prior to the bill's publication, Morrison and Ede appealed to Labour backbenchers to save the possible (a penal reform bill) by foregoing the perfect (a bill that also abolished capital punishment).

There is less evidence, at least before mid-1948, for a third explanation that says abolition was a potential vote-loser and had to be dropped. I would agree that Herbert Morrison's pragmatic socialism meant he believed, as Francis Williams said, "in not getting too far ahead of public opinion." From mid-1947, Morrison was the main advocate of "consolidation," which sought to slow the pace of reform and included avoiding policies that unnecessarily alienated voters. He was told that the bulk of the working-class (or broadly Labour) voters favored hanging and that abolitionism tended to be a middle-class fad. Moreover, the government had a huge social and economic program that Morrison, as leader of the House of Commons, did not want imperiled by a crisis over what seemed to him a fringe issue. Yet Morrison, by suspending the parliamentary party's standing orders, had permitted Labour backbenchers wider liberty to express disagreement with the leadership, and he was well versed in allowing backbench revolts quietly to defuse. This is doubtless what he expected to occur with the revolt over capital punishment. ${ }^{59}$

58. Times, July 26, July 29, Sept. 4, Sept. 20, and Nov. 3, 1947. See also Bailey, Delinquency, 291-302; Rose, Struggle, 231; Morris, Criminal Justice, 74-77.

59. See Francis Williams, Socialist Britain (New York: Viking Press, 1949), 80; Morgan, Labour People, 179, 183, 187; Steven Fielding, Peter Thompson, and Nick Tiratsoo, "England Arise!" The Labour Party and Popular Politics in 1940s Britain (Manchester: Manchester University Press, 1995), 175-79, 216; Bernard Donoughue and G. W. Jones, Herbert Morrison: Portrait of a Politician (London: Weidenfeld and Nicolson, 1973), 309. See also R. K. Alderman, "Discipline in the Parliamentary Labour Party 1945-51," Parliamentary Affairs 18 (1965): 296-97. 
Nor is a "bureaucratic" explanation of the government's behavior fully persuasive. The home secretary, it is claimed, became captive of the "departmental view," more strictly of the supposedly retentionist views, of Sir Alexander Maxwell, the permanent secretary, and Sir Frank Newsam, the deputy undersecretary. The predilections of the senior Home Office officials were reinforced, it is said, by the associations working on behalf of prison and police officers. The permanent officials in the Home Office called attention, of course, to the security aspects of the question. In early July 1947, Maxwell told Ede that many police and prison officers believed that criminals would be more likely to use lethal weapons if the penalty for murder were imprisonment rather than death and that those serving life sentences for murder would feel less restraint about killing prison officers. A related concern was a satisfactory alternative to death. Alexander Paterson, the former prison commissioner, told the 1930 Select Committee on Capital Punishment that imprisonment for terms beyond ten years was less humane than the death sentence. Paterson's views were possibly dear still to the permanent officials. But security considerations were only one dimension of departmental discussion, and not always the most important. ${ }^{60}$

When it comes to the supposedly retentionist views of department officials, the "bureaucratic" explanation is hard to sustain, at least for the most senior figure, Maxwell. In 1961, Gordon Rose implied that Maxwell and Newsam both shared the retentionist views of the former permanent secretary, Sir John Anderson (1922-1932). James Christoph reached no firm conclusion, but he pointed out that, in an interview, Ede had claimed that both officials were "at heart" abolitionists. Fenton Bresler maintained that Newsam was a decided retentionist and hence unpopular with the abolitionists. Herbert Morrison's biographers declared in 1973 that Maxwell "was a strong believer in the abolition of capital punishment." For my part, I have found nothing in the evidence to suggest that Maxwell was anything other than abolitionist in sentiment. ${ }^{61}$ Maxwell's advice, moreover, was essentially to avoid the free vote strategy, for a number of politically sound reasons, and instead to do one of two things: either resist an abolitionist amendment, or include abolition and back it to the hilt. The presumption must be that, above all, Maxwell simply wanted the government to take a consistent and defensible course of action, whether for or against abolition.

60. Maxwell minute, July 1, 1947, HO 45/21959/884452/203; Select Committee on Capital Punishment, P.P., 1930-31, VI (15), Minutes of Evidence, 599-60I (Alexander Paterson). The department also believed, for example, that there was still no general trend of public opinion in favour of abolition.

61. Rose, Struggle, 215; Christoph, Capital Punishment, 70, n. 10; Fenton Bresler, Reprieve. A Study of a System (London: Harrap, 1965), 75; Donoughue and Jones, Morrison, 310. 
And to what extent was Chuter Ede a captive of the "departmental view"? The character of the man points in that direction. Ede was a moderate, cautious, and practical politician, certainly no innovator, and, as such, likely to listen to his permanent officials. He tended to steer clear of controversy within the party, preferring the part of conciliator, and the capital punishment debate cannot have been to his liking. It is a telling point against him, moreover, that he was abolitionist both before and after his stint as home secretary, but retentionist when in office. Margery Fry, vice-president of the Howard League and a member of the Advisory Council on the Treatment of Offenders, claimed a few months later that "the conversion of the Home Secretary in favour of capital punishment seems unfortunately likely to be a reflection of one section of Home Office views." Above all, Ede believed that so disputatious a subject as capital punishment required separate legislative treatment, as did officials in the Home Office and the Cabinet Office. ${ }^{62}$ Perhaps, then, Ede was more than a mite "captive."

The preceding account of cabinet thinking leads me to suggest a fifth and final explanation for the government's behavior, one that underscores the incompatibility between a Parliamentary Labour Party chock-full of radical idealists and abolitionists, on the one hand, and a cabinet with only a few committed abolitionists, on the other. ${ }^{63}$ Only Shawcross and Soskice had "fire in their bellies" on this issue. They were up against the leader of the house, the home secretary, and a lord chancellor wielding the club of His Majesty's judges. Yet if the abolitionists were outgunned, the combination of strong backbench support for abolition and ministerial division together scuppered the idea of a separate bill to suspend or abolish the death penalty and impelled the strategy of the free vote in the House of Commons. The cabinet sought to find a way out of its difficulties by throwing the burden on the House by a free vote.

In early December 1947, abolitionists from the major parties (though

62. S. Margery Fry, "The Criminal Justice Bill," Political Quarterly 19 (1948): 115-16. For more on Ede, see Francis Williams, "Chuter Ede," Spectator, Oct. 1, 1948, 423-24, and Nothing So Strange (London: Cassell, 1970), 233; Morgan, Labour in Power, 54-55; Kevin Jefferys, ed., Labour and the Wartime Coalition: From the Diary of James Chuter Ede, 19411945 (London: Historians' Press, 1987), 8-9. Ede revised his views on capital punishment in the 1950s when serious doubts were raised about the conviction of Timothy Evans, who was executed on Ede's watch. Ede began to campaign for abolition of the death penalty and for a posthumous free pardon for Evans. See Jefferys, Labour and the Wartime Coalition, 15-16.

63. Norman Brook's minute of Nov. 18, 1947, PREM 8/739, indicated that not more than five cabinet ministers would vote for abolition, while ten or eleven supported the view that the time was not opportune to abolish the death penalty. But as for the Parliamentary Labour Party, one should not underestimate the pro-hanging views of many of the trade union or working class M.P.s, who made up some 38 percent of all Labour M.P.s. 
predominantly Labour members) decided to press for a five-year suspension of the death penalty rather than its complete abolition, presumably because this coincided with the recommendation of the 1930 Select Committee on Capital Punishment and would attract a wider body of parliamentary support. The scene was set for a free debate and free vote on the Report Stage of the Criminal Justice Bill, on the most controversial, and for some the most crucial, reform in the penal system. It would soon become clear that, by gambling on a free vote, the government had opened a Pandora's box of political troubles. ${ }^{64}$

\section{III}

In mid-March 1948, Prime Minister Attlee agreed, at Herbert Morrison's prompting, that the cabinet ought again to discuss the question of whether ministers should be free to vote according to conscience on the amendment for the abolition of the death penalty. The previous cabinet decision-that ministers should be free to vote for abolition-had the disadvantage that the division list would show afterwards that government members were not united in support of the advice given the Commons by the home secretary. At the cabinet meeting of April 8, Morrison argued that even on an issue like capital punishment, ministers who shared a collective responsibility ought not to vote in different lobbies, especially since it was "not wholly a matter for the individual's conscience ... it also involved questions of law and order for which the Government had a collective responsibility." He recognized that some of his colleagues held such strong views on the moral issues involved that they could not vote against abolition, but he wondered if their views "would not be sufficiently met if they abstained from voting." The cabinet agreed that members of the government who could not vote for retention of the death penalty should abstain from voting. All ministers and junior ministers outside the cabinet were so informed, as was the P.L.P. ${ }^{65}$ This was a heavy blow to the Silverman group, who were banking on the

64. Christoph, Capital Punishment, 42. The twenty-two abolitionists (led by Silverman) who met in the Commons also agreed to confine the change to the crime of murder (rather than all existing capital offenses) and to advocate as an alternative to hanging the usual sentence of life imprisonment. Between the Second Reading and the Report Stage, the various extra-parliamentary bodies (including the police and prison officers' associations and the NCADP) were busy canvassing M.P.s. See Christoph, Capital Punishment, 42-44. Some abolitionists were by now less optimistic about the outcome. In January 1948, Margery Fry told Professor Kinberg: "I'm very much afraid we are going to be defeated. A tremendous rise in crime ... has made people jumpy and vindictive." Quoted in Jones, Margery Fry, 220.

65. C.M. (48) 27th conclusions, Cabinet meeting, Apr. 8, 1948, CAB 128/12; Norman Brook minute, Mar. 19, 1948, PREM 8/739. At a stormy meeting of ministers outside the 
votes of sympathizers in the ministry. Ministers began to search their consciences. James Griffiths, minister of national insurance, informed Attlee: "as all through my life I have been for the abolition of the death penalty, I feel constrained to abstain from voting tonight." Kenneth Younger, undersecretary at the Home Office, and Ede's main assistant in steering the bill through the Commons, was allowed by Ede to abstain. ${ }^{66}$

At the Report Stage of the bill on April 14, the first order of business was the Silverman amendment, by now bearing the signatures of 147 M.P.s, proposing that for a period of five years (which might be extended by Order in Council on a prayer by both Houses) the death penalty should be suspended and sentence of life imprisonment substituted. This is not the place to review exhaustively the debate that took place in a packed House of Commons. Suffice it to say that Silverman tried to show the contradictory nature of the government's case. He took their case to be that the death penalty was, in principle, mistaken and ought to be abolished, but that it was "the wrong moment in which to live up to those principles." "[I]t is impossible to my mind," said Silverman, "to argue at one moment that the thing ought to be abolished some day because it is not a deterrent, but ought to be retained today because it is a deterrent." He also brought attention to the absence from the Front Bench at that moment of the chancellor of the exchequer (Stafford Cripps), the minister of health (Nye Bevan), and the four law officers of the Crown (which included Shawcross and Soskice). ${ }^{67}$

For a number of speakers in the debate, wartime events had manifestly reinforced their moralist convictions. Supporters of capital punishment argued that if it was morally right to hang war criminals, then it was right to use the death penalty for murderers at home. "We have just been hanging our defeated enemies after the trials at Nuremberg," said Quintin Hogg, Conservative M.P. for Oxford, and the attorney-general had prosecuted them "not as an act of war but as an act of what was claimed to be justice." If we were going to say that it was wrong in all circumstances to take life, Hogg continued, "then the time to say so was before Nuremberg and not immediately after." By contrast, opponents of capital punishment underlined the penchant for Britain's wartime enemies to use the death penalty. "It is not insignificant," said Elwyn Jones, who had been a member

cabinet, many objected strongly to the abandonment of the free vote. See Windlesham, Responses to Crime, 60.

66. Griffiths to Attlee, Apr. 14, 1948, PREM 8/739; Donoughue and Jones, Morrison, 430. The abolitionist cause was probably further weakened by a series of shocking murders in the months prior to the vote, including the murder of a police constable, all of which were given banner headlines in the press. See Christoph, Capital Punishment, 45.

67. Parl. Deb., 5th ser., Commons, 449, 986, Apr. 14, 1948, 986. The amendment had been tabled by an all-party list of sponsors. 
of the prosecution team at Nuremberg, "that one of the first acts of the Nazi Government was to restore the death penalty. . . Our democracy is a democracy that does not need the terror of the death penalty." In fine, the capital punishment debate in 1948 had a strong moral tone, whether retributive or humanitarian in sentiment. ${ }^{68}$

When the House divided on the Silverman clause, 245 voted yes, 222 voted no. By a slim majority, the Commons had approved a major change in the law of murder for the first time in almost a century. Immediately a roar of cheers went up. R. H. S. Crossman (who voted yes) later explained the emotional outburst:

For once the machine had been defeated by conscience; and a longstanding Party pledge had been fulfilled despite the dictates of expediency... It was a glorious victory. The violence of the jubilation revealed the frustration of a Party which longs to be able to choose between right and wrong and is constrained time after time to make do with the lesser evil. ${ }^{69}$

To its embarrassment, the government drew the bulk of its support from the Conservatives (no less than 134 of them). Of the 289 Labour Members who took part in the division, 215 voted for the clause (or three to one in favor). Party lines were thus clearly drawn on the issue, despite the government's argument that opinion transcended such lines. The most remarkable fact, however, is that of the seventy-two government members in the Commons, only twenty-eight voted against the amendment, while fortyfour availed themselves of the right to abstain, several pointedly remaining on the Front Bench during the division. Out of fourteen cabinet ministers eligible to vote in the Commons, nine voted against the amendment (including Attlee, Morrison, Bevin, and Ede), while Cripps, Bevan, and Harold Wilson (president of the Board of Trade) were present but abstained..$^{70}$ Another nine senior ministers not of cabinet rank and thirty-two junior ministers abstained, including all four law officers. (Indeed, none

68. Ibid., 1017 (Hogg), 1066 (Elwyn Jones). And see 1015 (John Paton, Labour M.P., and former secretary of the NCADP), 1093 (Reginald Paget, Labour M.P.). See also Lord Elwyn-Jones, In My Time: An Autobiography (London: Weidenfeld and Nicolson, 1983), chap. 10. Note, finally, that Christie Davies, Permissive Britain: Social Change in the Sixties and Seventies (London: Pitman, 1975), 36-41, used the 1948 debates to argue that the "causalist" arguments concerning deterrence and the possibility of error, which he felt were dominant by the 1950s and 1960s, were by no means as important in the "moralistic" $1940 \mathrm{~s}$.

69. New Statesman, Apr. 24, 1948, 326.

70. The other two cabinet ministers (Arthur Creech Jones and Philip Noel-Baker) were abroad. The nine ministers who voted for retention were Attlee, Morrison, Bevin, Ede, Arthur Woodburn (Scottish secretary), A. V. Alexander (minister of defence), George Isaacs (minister of labour), George Tomlinson (minister of education), and Tom Williams (minister of agriculture). Six of them were from working-class backgrounds. Two other cabinet ministers, Lords Jowitt and Addison, were in favor of retention, but they could not vote in the Commons. 
of the law officers had participated in the debate, despite the nature of the issue). ${ }^{11}$ Government dissension was awfully palpable.

What had gone wrong? The government presumably expected to win the vote. A year later, referring to the Commons vote, the lord chancellor said: "I frankly confess that I expected an answer in a different sense ..." And the Daily Telegraph stated that Morrison had believed there was a majority for the death penalty and thus the free vote would go in the government's favor. ${ }^{72}$ It seems, then, that the government miscalculated abolitionist strength on their own benches and wrongly expected there would be enough Opposition members to see them through. One can only wonder why the government did not do more to divine the mood and intention of their own supporters.

We are on firmer ground in saying that the government had failed to think through the full consequences of a defeat. For they now had to defend a policy they disliked in the House of Lords where they had few supporters and where the Conservative majority would doubtless delete the clause. If the clause came before the Commons again, the home secretary would have to ask the House to insist on a clause that the government opposed. Those who had abstained on the first occasion would be free to vote in support of abolition, while the ministers who were against the clause on the first occasion would be compelled to vote for the abolition that they previously opposed. If the Lords held firm, moreover, the government would be faced with a clash between the two chambers. Then the Lords would be able to maintain that they were defending the opinion of the Labour government, not to mention the will of the people, against the Commons' free vote and there would be a long delay in the passage of the Criminal Justice Bill. Lord Samuel surely encapsulated the government's plight when he said they "did not chastise the Back Benchers with Whips, but they are now themselves being chastised with scorpions." 73

First, in the aftermath of the abolitionist triumph, ministers agreed that

71. Mass-Observation Archive, TC 72, Box 1, File E; Times, Apr. 16, 1948; Christoph, Capital Punishment, 51; Morgan, Labour in Power, 62. According to James Callaghan, a junior minister at the time, he and the following government members abstained on April 14: Arthur Blenkinsop (parliamentary secretary at the Ministry of Pensions), George Buchanan (minister of pensions), Evan Durbin (parliamentary secretary at the Ministry of Works), Geoffrey de Freitas (undersecretary of state for the Air Ministry), and John Wheatley (lord advocate). Callaghan said that he abstained "as I could not vote as I would like to" (i.e., for abolition). He is quoted in K. O. Morgan, Callaghan: A Life (Oxford: Oxford University Press, 1997), 85. Sir Stafford Cripps was thought to have organized the passive resistance of the more than forty ministers (though Callaghan makes no mention of Cripps's influence). Margery Fry was particularly pleased that none of the law officers had voted for retention. Jones, Margery Fry, 220.

72. Parl. Deb., 5th ser., Lords, 155, April 28, 1948, 546; Daily Telegraph, Jun. 7, 1948.

73. Parl. Deb., 5th ser., Lords, 156, Jun. 1, 1948, 32. 
the government must accept the Commons' decision and must ask the House of Lords to accept the new clause. The cabinet also agreed with Ede's proposal that no death sentence for murder should be carried into effect while Parliament was still considering the Criminal Justice Bill. The House was duly told of this change in the exercise of the prerogative of mercy in capital cases, and the judges were asked to forego the black cap, the presence of the chaplain, and the "Lord have mercy on your soul," when a sentence of death was given. ${ }^{74}$

Second, it became clearer still that Parliamentary opinion and public opinion were at odds on the issue of capital punishment. Three opinion polls appeared in quick succession, indicating that the abolition or suspension of the death penalty was rejected by between two-thirds and three-quarters of respondents (see table below).$^{75}$ Neither sex, age, economic class, geographic location, nor religious persuasion made much difference to the result. Mass-Observation found that there was a steady rise in approval with increasing education (though even among those with higher secondary education, only 21 percent approved of the suspension measure) and that political affiliation influenced opinion (yet only 19 percent even of Labour supporters approved of the measure) ${ }^{76}$ Perhaps the most significant find-

74. See C.M. (48) 28th conclusion, Cabinet meeting, Apr. 15, 1948, CAB 128/12. The cabinet also decided that they should review at an early date "the existing powers of courts to impose the death penalty in the British Zone of Germany, in British Colonial territories, and in the Armed Forces of the Crown." See also the home secretary's statement on the prerogative of mercy in capital cases in the Commons, Apr. 16, 1948, and Ede's letter to the lord chief justice, Apr. 19, in HO 45/21958/884452/202A. Ede's announcement that he intended to advise His Majesty to commute every death sentence by conditional pardon to a sentence of penal servitude for life was eventually deemed to be unconstitutional, since the home secretary was assuming a dispensing power that Parliament had taken from the executive in James II's reign. Ede was required to make another statement to the House on June 10, 1948. See C.M. (48) 37th conclusions, Cabinet meeting, June 8, 1948, CAB 128/12.

75. See Mass-Observation Archive, File No. 2996, Capital Punishment Survey, Supplement No. 1, p. 14: "Results of the Three Surveys on the Experimental Abolition of the Death Penalty." This table was reproduced in L. R. England, "Capital Punishment and Open-Ended Questions," Public Opinion Quarterly 12 (1948): 413 (table 1). These figures are in marked contrast to the Gallup poll of November 1938, when 45 percent chose abolition. See the text at note 56 above.

76. See Daily Express, Apr. 29, 1948, 1; Gallup, ed., Public Opinion Polls, 174; Daily Telegraph, May 28, 1948, 1; Mass-Observation Archive, File No. 2996, Capital Punishment Survey, and File No. 3001, Three Surveys on Capital Punishment; Christoph, Capital Punishment, 43-44, 53-57. The British Gallup Poll was founded in 1937. For most surveys, Gallup Poll findings were based on samples of 1,000 interviews conducted in some 100 sampling points. Its poll findings were at this date published in the News Chronicle. The Mass-Observation survey interviewed over 6,000 people aged sixteen and over throughout England, Wales, and Scotland and used an "open-end" question ("How do you feel about the death penalty for murder being given up for 5 years?"), which allowed scope for spontaneous expressions 
ing, for present purposes, was the discovery by Mass-Observation that "the principle of a 'life for a life' is very much alive in many peoples' minds still ..." "77 Two-fifths of Mass-Observation's respondents spontaneously gave a reason for their attitude. Among those who disapproved of abolition, 40 percent felt it would result in an increase of crime. This was the most frequently expressed reason. Yet 26 percent cited the principle of retribution, prompting Mass-Observation to advise the Daily Telegraph, which published their poll: "It is well for both parties to know how deeply entrenched still in the minds of hundreds of thousands of citizens is the principle of retribution, quite irrespective of the merely practical merits or demerits of abolition." 78

Table 1. Experimental Abolition of the Death Penalty

\begin{tabular}{|c|c|c|c|}
\hline Attitude & Daily Express & $\begin{array}{c}\text { British Institute of } \\
\text { Public Opinion (Gallup) }\end{array}$ & Mass-Observation \\
\hline Approve & 14 & 26 & 13 \\
\hline Disapprove & 77 & 66 & 69 \\
\hline Degrees of murder & - & - & 7 \\
\hline Mixed feelings & - & - & 4 \\
\hline Miscellaneous & - & - & 2 \\
\hline Don't know & 9 & 8 & 5 \\
\hline
\end{tabular}

aFigures based only on those who had heard of the experiment. A blank indicates that this category was not included in the published results.

Third, the lord chancellor, whose job it was to persuade the Lords to accept the new clause, felt all at sea. "The more I think about the conclusion to which the Commons came," he wrote to the lord chief justice, "the more deeply I am disturbed by it. I don't see that we can do anything in our House for I feel sure that the Commons would resent any alteration." Jowitt concluded: "I am personally placed in an extremely difficult position about the whole thing and wonder what on earth I shall say about it."

of opinions. For more on M-O, see Angus Calder, "Mass-Observation 1937-1949," in Essays on the History of British Sociological Research, ed. Martin Bulmer (Cambridge: Cambridge University Press, 1985), 121-36.

77. Mass-Observation Archive, File No. 2996, Capital Punishment Survey, 9.

78. Mass-Observation Archive, TC 72, Capital Punishment Survey, Box 1, File B, May 1948 ("Mass Observation and Opinion Polls"), emphasis in the original. M-O's finding gained confirmation in August 1948 when Gallup asked the question: "What do you think is the main reason for sentencing a murderer to death-because he deserves it, or because it will stop other people committing murders?" The result was: Desert, 45 percent; Stop others, 43 percent; Don't know, 12 percent. See Gallup, ed., Public Opinion Polls, 180. 
Goddard, L.C.J., sympathized: "Like you, I feel this vote is disasterous (sic). I believe it has no public demand behind it except a vocal body who have always agitated for abolition. One thing which I fear may result is retaliation from which, happily, this country has hitherto been free." 79

If the government hoped to persuade the House of Lords to accept the new clause, they could have chosen no worse advocate than the lord chancellor. Arguing in the most backhanded manner that he, the head of the judiciary, was opposed to the experiment, but that the Lords should nonetheless make it, was hardly calculated to win over such determined opponents as Lords Simon and Samuel. In the second day's debate, Jowitt was more forthright still:

I was a party to a bargain. I agreed that this matter should be left to a free vote, and I agreed to stand by the result of that free vote. . . I do not suggest for a moment, however, that your Lordships are bound . . . your Lordships have constitutionally... the perfect right to send the clause back to another place for further consideration if you are so minded ${ }^{80}$

And, of course, many of the Lords were so minded.

Again, I will not attempt to give a comprehensive review of the four days of debate in the Lords. Suffice it to emphasize three important points. The first is that what has been called the "law-and-order group" among the law lords, which emerged with the postwar rise in recorded crime, were in full cry. Lord Oaksey, a lord of appeal (who, as Lord Justice Lawrence, had

79. Jowitt to Goddard, Apr. 19, 1948; Goddard to Jowitt, Apr. 20, 1948, LCO 2/3340. Surprisingly, the Daily Mail, a retentionist paper, advised the House of Lords not to reject the abolitionist clause. Hollis, Homicide Act, 17. Other responses to the free vote were more predictable. The Police Chronicle warned that British policemen would now need to be armed; the chairman of the Prison Officers' Association vowed to press for compensation for dependents of officers killed in prison as a result of abolition. See Christoph, Capital Punishment, 52. And Winston Churchill, Opposition leader, denounced the cabinet for having left "this grave decision on Capital Punishment to the casual vote of the most unrepresentative and irresponsible House of Commons that ever sat at Westminster." Speech of April 21,1948 , to the Annual Conference of Conservative Women, quoted in Martin Gilbert, Winston S. Churchill (Boston: Houghton Mifflin, 1988), 8:400-401.

80. Parl. Deb., 5th ser., Lords, 155, Apr. 28, 1948, 545-46. See also Parl. Deb., 5th ser., Lords, Apr. 27, 1948, 396-99. A few years later, Jowitt told the House of Lords that when the Criminal Justice Bill came before the House, "I was one of those who took the view and, I say quite frankly advised behind the scenes, that we should insist upon the retention of capital punishment." Parl. Deb., 5th ser., Lords, 185, Dec. 16, 1953, 149-50. According to Lord Longford, Jowitt thought the secret of advocacy was to find the worst thing an opponent could say about your case and say it yourself. In the Lords, moreover, "he seemed to identify himself emotionally with the huge Conservative majority." See Frank Pakenham, Earl of Longford, Five Lives (London: Hutchinson, 1964), 81. Jowitt was also said to be a poor advocate when he knew he had a difficult position. See Heuston, Lives, 70, 98, 115; Shawcross, Life Sentence, 65. 
acted as president of the Nuremberg Tribunal in 1945), was an assertive retentionist with regard to both corporal and capital punishment, for both retributive and deterrent reasons. "Is this the time in which to introduce this change in the law?" he asked the House (shades of Lords Eldon and Ellenborough). "It seems to me somewhat difficult to justify putting to death your enemies" (in Germany), he argued, "and at practically the same time abolish the penalty of death in your own country." Additionally, the time was not ripe "because there is a lack of discipline in the country which gives rise to this wave of crime." 81 He was ably seconded by the lord chief justice, Lord Goddard, or "Lord God-damn," as Churchill styled him. In what was his maiden speech, Goddard delivered a furious assault on those who believed "that punishment should never be punitive, only reformative." Large numbers of criminals (namely professional abortionists, the homosexual who corrupts small boys, and professional receivers) were not sentenced for reformative purposes, said Goddard, but to show that such conduct would result in punitive consequences. "I have never yet understood how you can make the criminal law a deterrent unless it is also punitive." He continued: "If the criminal law of this country is to be respected, it must be in accordance with public opinion ... I cannot believe that the public opinion (or I would rather call it the public conscience) of this country will tolerate that persons who deliberately condemn others to painful and, it may be, lingering deaths should be allowed to live." The conclusion was foregone: "I believe that there are many many cases where the murderer should be destroyed." 82

81. Parl. Deb., 5th ser., Lords, 155, April 27, 1948, 430-31. In the later debate, Oaksey concluded his speech by declaring, "It is all wrong to say that punishment has nothing to do with retribution. There are certain cases which shock the conscience of every ordinary man." Parl. Deb., 5th ser., Lords, 157, July 20, 1948, 1047-48. See also Stevens, Law and Politics, 360-61.

82. Ibid., 490-94. Goddard also said that the twenty King's Bench judges were all in favor of retaining the death penalty. In late June, however, he had to admit that he had been in error; two judges had since told him that they supported the proposal to suspend the death penalty for five years. See Times, July 1, 1948; Fenton Bresler, Lord Goddard: A Biography of Rayner Goddard, Lord Chief Justice of England (London: Harrap, 1977), 184 and note. Goddard later tabled an amendment to the Criminal Justice Bill that would have limited the abolition of corporal punishment to the cat o' nine tails. Whipping with a birch rod would have remained. The amendment carried in a thinly attended House of Lords by twentynine to seventeen. In the Commons, the amendment was rejected, and the Lords gave way. See Parl. Deb., 5th ser., Lords, 156, June 2, 1948, 191-215.

A month after his appointment as lord chief justice, in the case of Harry John McBain, Goddard had signaled his response to the postwar crime wave. "In the state of crime in this country the time has now come when sentences must be severe, and where a prisoner appeals against sentence this Court will not shrink from increasing the sentence if it thinks it right to do so." Criminal Appeals Report 31 (1946): 115. Goddard retired in 1958 and died 
Second, the bishops of the Church of England provided choral backing for the legal leads. Only the Bishop of Chichester voted for abolition. A more representative figure was Mervyn Haigh, the lord bishop of Winchester. The Criminal Justice Bill, he remarked, was "infected at some points by an excessive fear of punishment. I certainly view with some alarm the extent to which the door is opened to the opinions and influence of more medical men and more psychiatrists." But perhaps, he continued, "the heyday of what I might call Patersonian optimism in this matter has, at any rate for the time being, passed." Haigh took the opportunity, therefore, to remind the Lords of "the primitive framework whereby punishment is awarded by the State in a quite objective way":

... I believe that the deepest point is not just whether the death penalty deters a certain number of people from committing murder... but what the effect of abolishing the death penalty on the education of the conscience of the community as a whole will be; how far it will affect the general sense of the wickedness of wickedness, the general sense of the criminality of crime, and the general sense that some crimes are infinitely more heinous than others. ${ }^{83}$

The death penalty, he concluded, still aroused among large numbers of people "what I can only describe as a quasi-religious sense of awe." 84

Finally, a number of speakers recommended the alternative course of limiting the infliction of the death penalty to certain categories of the gravest cases. Lord Samuel, for example, suggested that all murderers should be reprieved except in four categories: political assassins, murderers of police officers, murderers of prison officers, and murders of a "planned and callous character." 85 Soon schemes of grading murders would be all the rage.

On June 2 , the Silverman clause was defeated by 181 votes to $28 .^{86}$ The rest of the bill was approved by the Lords, even the abolition of corporal punishment. Only hope stayed inside Pandora's box.

in 1971. His death prompted one of his severest critics, Bernard Levin, to declare that "Goddard's influence on the cause of penal reform was almost unrelievedly malign." Times, June 8, 1971. And see Levin, "Brother Savage," Spectator, 16 May 1958, 629. See also Shimon Shetreet, Judges on Trial (Amsterdam: North-Holland Publishing, 1976); Stevens, Law and Politics, 362.

83. Parl. Deb., 5th ser., Lords, 155, April 27, 1948, 426.

84. Ibid., 427.

85. Ibid., 415-18.

86. Ibid., 156, June 2, 1948, 102 and following. The Lords had not divided in April on the bill's Second Reading. The twenty-eight supporters of the Silverman clause included twenty-two Labour peers, three Conservative peers, and three others. The total number voting was large by upper chamber standards, pointing to the role of "backwoodsmen," or Conservative peers who come out only on emotive occasions. See P. A. Bromhead, The House of Lords and Contemporary Politics, 1911-1957 (London: Routledge and Paul, 1958), 47 and 218, n. 2. 
Confronted by a Lords' revolt, what could the Labour government do? The strongest response would be to defy the Lords, namely to invoke the Parliament Act and stand behind the clause, albeit one they had originally opposed. At this time, however, the government was wary of challenging the Lords on anything. The weakest response would be to defer to the Lords, namely to accept the bill denuded of the abolitionist clause and face the wrath of many in the Parliamentary Labour Party. A third way would be either to extend the use of the royal prerogative of mercy (which abolitionists considered no advance at all) or to find a compromise clause satisfactory to both retentionists and abolitionists.

The press response to the Lords' vote gestured toward a compromise clause, establishing degrees of murder. The News Chronicle, for example, advised the government "that there were comparatively few in the House of Lords who desire the permanent retention of the death penalty in its present form." Leading the charge for a compromise clause was Lord Chancellor Jowitt. He had been struck by the archbishop of Canterbury's opinion during the Second Reading debate that the country could not now go back to the status quo. In addition, he wished to avoid a clash with the House of Lords at a moment when the press was waxing lyrical about how the Lords' delaying power had been used in the public interest. Jowitt feared that if the abolition clause was restored in the Commons, the Lords would again reject it, since they would know that, at a time when the Labour government aimed to reduce the Lords' veto power from two years to one, they had no better case for demonstrating their value as a revising chamber. ${ }^{87}$

The day following the Lords' vote, the cabinet, on the advice of the home secretary, decided to recommend to the P.L.P. that they accept a compromise clause retaining the death penalty for certain specified classes of murder. The lord chancellor had drafted a clause to this end. Ministers were swayed by two considerations. First, "it seemed likely that the balance of public opinion throughout the country was against the clause." To be sure, the Daily Telegraph claimed that "privately, constituency representatives submitted that votes were being lost to the party over this issue;" and closer to home, the Daily Herald maintained that many M.P.s who had either voted for suspension or abstained "have been impressed by the volume of criticism from their constituencies." 88 Second, if the Commons' decision no longer reflected the present mood of public opinion, this was not the mo-

87. News Chronicle, June 4, 1948. See also Times, June 3, 1948, 5; minute of S. Hoare, Assistant Under Secretary of State, June 2, 1948, HO 45/21962/884452.

88. C.M. (48) 35th conclusion, Cabinet meeting, June 3, 1948, CAB 128/12; Daily Telegraph, June 4, 1948, 1; Daily Herald, June 5, 1948, 1. 
ment to clash with the Lords on this issue. The debate on the Second Reading of the Parliament bill was underway, and the government had argued that the upper chamber "was not competent to interpret the popular will as against the judgment of the House of Commons." A battle with the Lords over the death penalty, which placed the peers in as strong a position with regard to public opinion as they were likely to attain, would give the lie to this argument. ${ }^{89}$

The cabinet hoped, finally, that a majority of the P.L.P. might be persuaded to vote in favor of such a compromise, especially since they could be told that the clause had been unanimously approved by the cabinet. Even Cripps and Bevan were prepared to support the compromise. The attorneygeneral, Shawcross, was obviously not at this cabinet meeting, since, to judge from his memoirs, he felt strongly that the clause suspending the death penalty should be restored by the Commons. Browbeaten by Attlee and Morrison not to split "on an issue on which public opinion was so clear," Shawcross agreed to vote with the government, but then resign (an act he never took). ${ }^{90}$

On June 9, Ede, Cripps, and Morrison persuaded the P.L.P. to accept the compromise clause..$^{91}$ The next task, which was never likely to be easy, was to draft an acceptable clause. The new clause was eventually drafted on the basis that the penalty for murder should ordinarily be life imprisonment, but that the death penalty should be retained for those types of murder that were the main cause of public anxiety and for which the deterrent effect of the death penalty was likely to be more powerful than it was in other cases. The clause did not attempt to define degrees of murder or to distinguish between types of murder according to the moral gravity of the crime. Nor was it drawn so as to include premeditated murders and exclude unpremeditated ones.

Instead, the clause reserved the death penalty for (i) murder incidental to the commission of offenses of robbery, burglary, and housebreaking, violence by gangs, offenses involving the use of explosives, and sexual offenses; (ii) murder committed in the course of resisting or avoiding arrest, of escaping from lawful custody, or obstructing the police or persons assisting the police; (iii) murder by the "systematic administration" of poison; (iv) murder of a prison officer; and (v) for a second murder. In

89. C.M. (48) 35th conclusion, Cabinet meeting, June 3, 1948, CAB 128/12.

90. Shawcross, Life Sentence, 168. The Daily Mirror, June 7, 1948, 5, wrongly stated that Cripps and Bevan were pressing the cabinet to stand by the original decision of the Commons.

91. See News Chronicle, June 10, 1948, 1. Morrison urged acceptance for tactical reasons. It was much better to fight the House of Lords over the bill for steel nationalization than over capital punishment. 
effect, the clause divided murder into two broad categories, capital and noncapital. The Home Office calculated that if this clause became law, the number of actual executions would be reduced by more than half, and the number of cases in which the sentence of death was pronounced by even more. $^{92}$

The compromise clause was introduced in the Commons by AttorneyGeneral Shawcross, in a more vigorous manner than might have been expected of a confirmed abolitionist. Winston Churchill, Opposition leader, and other Conservative members then had a field day pointing out the anomalies and illogicalities in the clause. "All the most frequent types of murder," said Churchill, "that is to say, wounding, stabbing, strangling, drowning, etc., committed for all the most wicked motives, jealousy, greed, revenge, etc., will not carry the death penalty, because that penalty will only apply in such cases if the offence is committed by three or more persons." Both parties had issued three-line whips, so, unsurprisingly, the Commons agreed to substitute the government's new clause by 307 votes to $209 . .^{93}$

As Shawcross handed the baton to the lord chancellor, he warned that the clause was difficult to defend on its intrinsic merits. He had tried in his speech to justify the various categories for which the government had retained the death penalty, on the ground that it would operate as a deterrent in these cases:

This argument rather breaks down in regard to the poisoning case, the truth being that we included this, and, indeed, one or two of the other categories [e.g., two murders], not because the death penalty was a deterrent, but because public opinion demands its imposition by way of retribution in these types of case. As, however, we are sticking to the view ... that the death penalty cannot possibly be justified on the ground of retribution, we can hardly admit that any of the categories in which we are retaining the death penalty are included on that ground.

He concluded his letter to Jowitt by saying: "I am not at all sure that public feeling about the proposed abolition of the death penalty is nearly as strong as is sometimes thought. ... There is some rather ill informed public anxiety, no doubt, but I am afraid the truth is that it is being artificially stirred up in some places for political reasons." Jowitt replied the day after the Lords' debate on the compromise clause to say he had had "a very

92. Maxwell minute, June 29, 1948, HO 45/21962/884452.

93. Parl. Deb., 5th ser., Commons, 453, July 15, 1948, 1442. A second amendment-to suspend capital punishment for five years but to leave it to the home secretary to order when the period would begin-was pressed by Labour M.P. Anthony Greenwood. Even Sydney Silverman opposed the amendment on the grounds that it would place too great a burden on the home secretary's shoulders. The amendment was defeated. 
uncomfortable time" with the hanging clause and that "Simon was almost unbearable, making a speech full of "malice aforethought." "94 Lord Simon certainly pulled no punches. "[T]his clause is simply shot to pieces," he said; "this clause is rightly denounced as being a quite impossible and utterly absurd provision." Alas, Templewood, the leader of the abolitionists in the Lords, also declared the clause to be unworkable. And even Jowitt, in a study of half-heartedness, conceded that possibly he had gone "a little too far in assenting to this scheme. I daresay it is not very well drafted." 95 Not surprisingly, the clause was decisively rejected by ninety-nine votes to nineteen.

The opposition to the compromise clause points again to the strength of the morality of blame and desert. The clause was a deliberate attempt to avoid questions of retribution and degrees of culpability. Capital murders were not defined by reference to moral guilt, for they were neither the most abhorrent murders, nor those that had been most clearly premeditated. This entire approach stuck in the craw of all retributivists. They were not willing to accept a system in which the wicked might be more severely punished than the very wicked. To be acceptable to them, then, a compromise clause would have had to be based firmly and squarely upon degrees of heinousness. ${ }^{96}$

The nettle was back in the government's hand. It had four choices. First, it could put the bill through under the Parliament Act procedure, and include a provision about capital punishment. But this procedure could be applied only to the bill as it first left the Commons, the one including the Silverman clause suspending the death penalty. The government could hardly force this into law with popular support so lacking. Second, it could deal with capital punishment in a separate bill in the next session. But could the government find a suitable legislative form for this? The compromise clause had been shot out of the sky. Third, it could seek some further compromise that the Lords would accept, but Parliamentary time was running out for this expedient. And, fourth, it could accept the Lords' rejection of the compromise clause and thus ensure that the rest of the bill could pass in the present session. The cabinet chose the last course, and Ede advised the Commons on July 22 to drop the compromise clause. Morrison seconded this advice, reminding the House that the main issue was whether they were going to save a measure "for making a big landmark in the progressive administration of criminal justice and the criminal law." The gov-

94. Shawcross to Jowitt, July 19, 1948; Jowitt to Shawcross, July 21, 1948, in LCO 2/ 3341 .

95. Parl. Deb., 5th ser., Lords, 157, July 20, 1948, 1055, 1070.

96. Cf. the discussion of the 1957 Homicide Act in Christie, "Power of Life and Death," $365-67$. 
ernment won the vote by 215 to 34 . Only 129 of the 215 were Labour members, and thus two-thirds of the party voting strength failed to take part (including 14 senior ministers). ${ }^{97}$ On July 30, 1948, the Criminal Justice Act received the Royal Assent.

In early November, the home secretary recommended to his colleagues the appointment of a royal commission on capital punishment. At this stage, the terms of reference included the issue of abolition. The cabinet endorsed the proposal, but restricted the enquiry to the question of whether liability to suffer capital punishment should be limited or modified. In effect, some new method of classifying murders by degrees, which the Lords had ridiculed, the Opposition in the Commons had opposed, and the abolitionists disliked, formed the royal commission's terms of reference. On November 18 , Ede announced the proposal to set up a royal commission. ${ }^{98}$ No one expected a report in the lifetime of the present Parliament, or before the 1950 election. But then delay was one of the prime virtues of a royal commission. On the same day, Stanley Joseph Clark, thirty-four, was hanged at Norwich prison for murdering a chambermaid, the first person to be executed since the controversy over the Criminal Justice Bill. The bishop of Norwich spent the last thirty minutes before execution with Clark. A day later, Peter Griffiths, twenty-two, was executed at Walton Gaol, Liverpool, for battering a three-year-old child to death. ${ }^{99}$ The hangman was back in business.

The royal commission took until September 1953 to submit its report. Its recommendations (for example, that the statutory age for executions should be raised from eighteen to twenty-one) were incidental compared to the conclusions: that it was impossible to classify murders so as to confine the death penalty to the more heinous and that there was no convincing evidence that capital punishment had a uniquely deterrent effect in preventing murder. Though the terms of reference precluded the judgment, what the commission implicitly proclaimed was that the existing law could not be satisfactorily amended except by abolition. ${ }^{100}$ The Conserva-

97. Norman Brook minute, July 21, 1948, PREM 8/739; C.M. (48) 53d conclusions, Cabinet meeting, July 22, 1948, CAB 128/13; Parl. Deb., 5th ser., Commons, 454, July 22, 1948, 707-11, 750; Mass-Observation Archive, TC 72, Box 1, File E. In the event, Attorney-General Shawcross did vote with the government, for which Attlee thanked him. See Shawcross, Life Sentence, 169.

98. See C.P. (48) 252, Nov. 3, 1948, CAB 129/30; C.M. (48) 74th conclusions, Cabinet meeting, Nov. 18, 1948, CAB 128/13; Brook minute, Nov. 6, 1948, PREM 8/739. The appointment of a royal commission took abolitionists by surprise. The NCADP no longer existed, so the Howard League had to take over. See Jones, Margery Fry, 225.

99. Times, Nov. 19, 1948, 5; Nov. 20, 1948, 3.

100. Royal Commission on Capital Punishment, 1949-1953, Cmd. 8932 (1953; reprint, London: Her Majesty's Stationery Office, 1965). See also Hollis, Homicide Act, chaps. 2-3. 
tive government of the day rejected all the main recommendations of the commission and declined to introduce legislation to amend the law of murder. Within a few years, however, in a desperate gambit to forestall outright abolition, the Conservatives conceded the 1957 Homicide Act. ${ }^{101}$ In its forlorn attempt to distinguish between capital and noncapital murder, the act caused such confusion that even the senior judges withdrew their backing. The Homicide Act's failure, plus several controversial executions (Bentley, Ellis, and Evans-the latter case flying in the face of those who would insist that no mistaken execution had ever been carried out), so changed opinion that when Labour returned to office in 1964, abolition was assured. In 1965, capital punishment for murder was suspended for five years, at the end of which it was abolished. ${ }^{102}$ The shadow of the gallows no longer fell across the land.

\section{$\mathbf{V}$}

The outcome of the crisis between 1945 and 1948 was to leave the law of capital punishment exactly as it was. For an abolitionist movement that had anticipated the final triumph of a century-long campaign to abolish the death penalty in Britain, this was a deeply disappointing result. Abolitionists had looked forward to providing the capstone to the Criminal Justice Act, the symbolic emblem of a new penal future that "liberal progressives" had so patiently constructed throughout the interwar years. Instead, they had traveled for nine months on a Parliamentary switchback, which came to a halt at its starting point. Parliament passed the kind of law that the government had asked for in November 1947, one shorn of a clause to abolish or suspend the death penalty. The capital sentence was to be re-

101. The Homicide Act abolished the death penalty for all murders except those done in course of furtherance of theft, by shooting or explosion, in resisting arrest or escaping from custody, murder of a police officer, and of a prison officer by a prisoner, and for repeated murders. The penalty for all other murders was life imprisonment.

102. See Block and Hostettler, Hanging in the Balance, chaps. 17-19; "Murder (Abolition of Death Penalty) Bill," Parl. Deb., 5th ser., Commons, 704, Dec. 21, 1964, 870. The vote on Second Reading was Ayes 355, Noes 170. See also "Murder (Abolition of Death Penalty)," Parl. Deb., 5th ser., Commons, 793, Dec. 16, 1969, 1148. The vote on the motion, That the Murder (Abolition of Death Penalty) Act 1965 shall not expire, was Ayes 343, Noes 185. After 1969, the death penalty remained for treason, mutiny, and certain other offenses specified in the Armed Forces Act, 1966. However, by virtue of the Crime and Disorder Act 1998, s. 36, and the Human Rights Act 1998, s. 21(5)_following the signing by the prime minister of the Sixth Protocol of the European Convention on Human Rightsthe death penalty, whether for military or for civilian offenses, is now abolished completely. Article 2 of the Convention permits a state to reintroduce the death penalty in wartime. 
tained, if more sparingly used. It had been a tortuous journey, one marked by ironies, dilemmas, embarrassments, and recriminations. It was not the ride the abolitionists had paid for. And it could, they felt, have been avoided.

The government had a huge majority in the Commons, a large segment of which was avowedly abolitionist. The press, moreover, was far from retentionist in sentiment. In the abolitionist corner were the Times, News Chronicle, Manchester Guardian, Daily Mirror, Daily Herald, and Reynolds News, plus such weeklies as the Observer, Spectator, Economist, and New Statesman. ${ }^{103}$ There can have been few issues raised by the postwar Labour government that attracted such widespread press backing. This was due, in part, to the merely suspensory nature of the amendment. As the Times argued, a five-year experiment would lead to evidence whereby a lasting decision could be taken. ${ }^{104} \mathrm{How}$, then, could the government temporize in this matter, defer to the Conservative peers, and fail to offer clear leadership?

All this overlooked the peculiar character of capital punishment. It may in principle be the apex of the country's penal system, but in practice governments have treated it as a special case. The death penalty called up the strongest emotions; it touched the deepest fears and values. Few people were without opinions on the state's right to exact death; few governments were willing to go ahead of opinion on so volatile and unpredictable an issue. Fearing an emotionally charged controversy, parties and governments kept their heads down. Parties made no mention of capital punishment in their manifestos, lest a commitment either way became a hostage to fortune. When in power and when made to confront the issue, governments trusted to the free vote, to Parliament as a body of private consciences, to the fiction that capital punishment was an issue of public morality that cut across party lines.

By so refusing to treat capital punishment as an integral part of their legislative program, the Attlee administration opened a Pandora's box of troubles. Only when the government faced up to their responsibilities was the box closed, but between the opening and the closing, confusion reigned. Having decided that the death penalty should be retained, the Labour cabinet lacked the courage to make it government policy. Consequently, what

103. See The Press and Its Readers: A Report Prepared by Mass-Observation for the Advertising Service Guild (London: Art and Technics, 1949), 81-84. Editorially opposed to the suspension of the death penalty were the Daily Telegraph, Daily Mail, Daily Express, and Daily Graphic. As the report also made clear, however, the press "has had little opinion-forming influence on this issue." With the single exception of the Daily Worker, the Communist Party newspaper, "the majority of readers of every paper are against suspension" (82, emphasis in original).

104. Times, April 14, 1948, 5. 
the majority of ministers believed was necessary - to retain capital punishment-was left to a free vote of the Commons, which unexpectedly went in favor of abolition. A measure without strong government backing was doomed in a House of Lords where Conservative and retentionist feeling predominated. The lord chancellor's lackluster performance was an effective nod and a wink to the peers to resist abolition. Jowitt had the sanguinary support, moreover, of His Majesty's judges, especially Lord Chief Justice Goddard, whose reign of retributive bombast was underway. The upper chamber's lex talionis was reinforced, finally, by the weight of public opinion. The Lords could legitimately claim that on the issue of capital punishment they were closer to the vox populi than the House of Commons. It was hard to deny the finding that close to three in every four people were unfavorable to abolition, other than by pleading that public opinion was uninformed, a doubtful argument for a People's Party. When the peers resisted, the government declined to face them down, adopting instead the face-saving formula of degrees of murder, so shot through with philosophic contradictions and practical illogicalities that it took the issue to new risible depths. What had gone so wrong? "Funk Rule!" the Daily Mirror concluded, by which it meant the lack of clear leadership on a vital moral and legal issue. ${ }^{105}$

One other factor was decisive in the failure to abolish capital punishment. The postwar years proved much less propitious for reform of the criminal code than abolitionists were expecting. In the thirties, parliamentary, public, and even judicial opinion seemed to be moving towards abolition, in tandem with a strong desire to recalibrate the principles of punishment for all criminal offenders. The prison commissioners themselves were in the van of a broad-based campaign to demote retribution in favor of rehabilitation. The 1938 Criminal Justice Bill would have given legislative warrant to the reformative treatment of prisoners. Between 1939 and 1947 , however, the rate of reported crime rose markedly, and the very act of homicide appeared to take on a more malevolent character. In this setting, the renewed attempt to abolish the death penalty sounded the tocsin. It aroused those who believed that the antisocial tendencies proceeding from the war had far from spent their force to proclaim that this was not the time to be weakening the penal armory. ${ }^{106}$ Corporal punishment could not be

105. Daily Mirror, June $11,1948,2$. The fact that a reprise of the 1948 events was enacted in 1956, when a Conservative administration confronted the same issue, suggests that it was the character of capital punishment as much as the party handling the issue that influenced these events. See Nigel Nicolson, People and Parliament (1958; reprint, Westport: Greenwood Publishing Group, 1974), 86.

106. This is not to imply that postwar debate was sharply polarized on every issue of penal reform. The Conservative Party continued to understand juvenile crime, for example, in progressive ways. See Youth Astray (London: Conservative Political Centre, 1946). This report recommended the abolition of whipping for boys under fourteen and of imprisonment for persons under seventeen. See also Bailey, Delinquency, 290. 
saved; all the more reason, then, to cleave to the sword of Damocles. Retaining the gallows was not only about deterring murder, as important as that mandate remained; it was also about satisfying, expressing, and educating the public instinct to condemn crimes that menaced the community. The lord bishop of Winchester had said as much in closing his speech on the Criminal Justice Bill in 1948: "I urge that the question to be considered is not simply whether there will be a few more murders or a few less, but the whole attitude of the British people to what I have described as the criminality of crime, and to the majesty of the whole system of law from top to bottom."107

It is this final factor that prompts the conclusion that the turbulent postwar conflict over the death penalty marks a critical moment in criminal justice history. Despite the good intentions and best efforts of administrators and penal reformers in the aftermath of the First World War, the structure of criminal justice experienced no radical transformation during this period. The "classical" jurisprudential axioms of personal responsibility, deterrence, and a due proportion between crime and punishment retained much of their authority. In the criminal courts, rehabilitation was honored more in the breach than the observance. Yet the tide was turning between the wars. Recorded crime rose slowly, prison populations declined, and innovations such as open prisons were introduced. A progressive reformism, which had points in common with a "positivist" criminology, guided penal practice. And it shaped the legislative climax of the era, the Criminal Justice Bill. By rights, the postwar Labour government should have launched an era of unashamed rehabilitation, in which the gallows were dismantled once and for all. That it did not is surely testimony to the enduring political, judicial, and public resistance to the reforming ethos. It meant that for a while longer yet, penal debate would be consumed by the agitation to get rid of the last remaining human sacrifice. 